IZA DP No. 8292

Immigrants, Labor Market Performance, and Social Insurance

Bernt Bratsberg

Oddbjørn Raaum

Knut Røed

June 2014 


\title{
Immigrants, Labor Market Performance, and Social Insurance
}

\author{
Bernt Bratsberg \\ Ragnar Frisch Centre for Economic Research \\ Oddbjørn Raaum \\ Ragnar Frisch Centre for Economic Research \\ Knut Røed \\ Ragnar Frisch Centre for Economic Research \\ and IZA
}

Discussion Paper No. 8292

June 2014

IZA

P.O. Box 7240

53072 Bonn

Germany

Phone: +49-228-3894-0

Fax: +49-228-3894-180

E-mail: iza@iza.org

Any opinions expressed here are those of the author(s) and not those of IZA. Research published in this series may include views on policy, but the institute itself takes no institutional policy positions. The IZA research network is committed to the IZA Guiding Principles of Research Integrity.

The Institute for the Study of Labor (IZA) in Bonn is a local and virtual international research center and a place of communication between science, politics and business. IZA is an independent nonprofit organization supported by Deutsche Post Foundation. The center is associated with the University of Bonn and offers a stimulating research environment through its international network, workshops and conferences, data service, project support, research visits and doctoral program. IZA engages in (i) original and internationally competitive research in all fields of labor economics, (ii) development of policy concepts, and (iii) dissemination of research results and concepts to the interested public.

IZA Discussion Papers often represent preliminary work and are circulated to encourage discussion. Citation of such a paper should account for its provisional character. A revised version may be available directly from the author. 


\section{ABSTRACT}

\section{Immigrants, Labor Market Performance, and Social Insurance*}

Using longitudinal data from the date of arrival, we study long-term labor market and social insurance outcomes for all major immigrant cohorts to Norway since 1970. Immigrants from high-income countries performed as natives, while labor migrants from low-income source countries had declining employment rates and increasing disability program participation over the lifecycle. Refugees and family migrants assimilated during the initial period upon arrival, but labor market convergence halted after a decade and was accompanied by rising social insurance rates. For the children of labor migrants of the 1970s, we uncover evidence of intergenerational assimilation in education, earnings and fertility.

JEL Classification: F22, H55, J22

Keywords: migration, assimilation, social insurance

Corresponding author:

Bernt Bratsberg

The Ragnar Frisch Centre for Economic Research

Gaustadalléen 21

0349 Oslo

Norway

E-mail: bernt.bratsberg@frisch.uio.no

\footnotetext{
*We are grateful for valuable comments from Christian Dustmann, Tommaso Frattini, seminar participants at the University of Hamburg, and two anonymous referees. Bratsberg acknowledges funding from the Norwegian Research Council (project "Work Life Challenges - workforce management and worker involvement solutions"), Raaum from the Ministry of Labour (project "Immigrants, Employment and Time since Arrival"), and Røed from the Norwegian Research Council (project "Social Insurance and Labor Market Inclusion in Norway"). The paper is also part of the research activities of the Centre of Equality, Social Organization, and Performance, University of Oslo. Data made available by Statistics Norway have been essential for this research.
} 


\section{Immigrants, labor market performance, and social insurance}

Economists and analysts often stress that, in a world with large cross-country productivity differences, liberalizing international migration could deliver a huge boost to global output (Kennan, 2013; The Economist, 2012). While many of the world's potential migrants undoubtedly would gain tremendously from free access to a high-productivity work environment, the fiscal consequences for receiving countries are less obvious (Preston, 2013). Prior evidence from Europe shows that migrants in many host countries are overrepresented among beneficiaries of non-contributory transfers (Boeri, 2010). And with the deeper integration of European labor markets, policy makers in highincome countries are concerned that the large cross-country differences in living standards and social insurance might generate "welfare migration" that puts pressure on existing social insurance institutions.

In the present paper, we examine the lifecycle patterns of employment, earnings, and social insurance claims of immigrants to a typical welfare state economy, Norway. Our analysis covers all major immigrant waves over the past four decades-spanning labor migrants of the early 1970s and the subsequent family immigration they generated during the 1970s and 1980s; the large cohorts of refugee arrivals during the 1980s and 1990s; and the recent wave of labor migrants from Eastern Europe since 2004. Based on longitudinal administrative register data, we study labor market performance and social insurance receipts for up to 40 years after arrival. The lifecycle perspective on labor market performance is of particular significance in welfare state economies with extensive social insurance programs for the simple reason that persons who are not employed tend to receive some kind of public transfer. Moving a person out of employment not only leads to loss of tax revenues, but very often also leads to the added costs of a tax-financed social insurance payment. The comprehensive welfare state may also influence the composition of migrant flows and the labor supply behavior of immigrants once they are established in the host country (Borjas and Trejo, 1993; Nannestad, 2004). In particular, the combination of a relatively compressed wage distribution and generous welfare transfers to persons outside the labor market, especially for families with (many) children, may seriously distort work incentives and undermine labor supply. The surge in labor migration following the eastwards expansions of the European Union has brought renewed interest in understanding the consequences of large differences in wages and welfare benefits across host and source countries. The experiences of recently arrived Eastern European labor migrants to Norway during the financial crisis present a particularly interesting case as we are able to track the employment and social insurance outcomes of individual migrants through the slump and the subsequent period of economic recovery.

Dustmann and Frattini (2013) present evidence from the UK that the direct fiscal contribution differs importantly by immigrant origin. With considerable variation in the composition of migrant flows across time and space (Bauer et al., 2000), the overall fiscal impacts will vary across destination countries depending on the relative skills and origin mix of the immigrant population. Although we do not assess the full fiscal consequences of immigration, we explicitly address the heterogeneity of the immigrant population and distinguish between early labor migrants from countries with similar living standards as Norway, those who came from developing countries, as well as post-accession labor migrants from new member countries of the European Union. Moreover, lifecycle profiles of employment and earnings of labor migrants, whose admission is based on a job contract, are 
expected to differ fundamentally from those of immigrants admitted through family ties and refugees admitted for protection.

While prior studies of immigrants' long-term performance in the Norwegian labor market have been mainly descriptive (e.g., Bratsberg et al., 2010), in this paper we complement descriptive overviews with regression-based analyses that seek to identify cohort-specific assimilation profiles by years since migration. From the objective of assessing fiscal consequences, the purely descriptive lifetime patterns of employment, earnings, and social insurance receipts may be more relevant, with underlying mechanisms and explanations of second-order interest. But, in order to gain knowledge about the conditions for successful or unsuccessful immigrant assimilation, we need to examine how immigrants' labor market performance is affected by their own characteristics and the economic environment with which they are confronted. Estimating assimilation profiles, we therefore control for individual characteristics such as age, human capital investments, and family situation, as well as cyclical conditions. Our findings show that, while the lifecycle labor market and social insurance careers of immigrants from Western Europe resembled those of natives, early 1970s labor migrants from developing countries had much shorter employment careers. After a decade of close to full employment, the labor immigrants from low-income source countries gradually lost ground in the labor market, with native-immigrant employment and earnings differentials growing monotonously with years since arrival along with a corresponding immigrant overrepresentation in social insurance programs. For the much larger groups of chain migrants that arrived later through family reunification, as well as for the refugee cohorts of the 1980s and 1990s, we do identify significant labor market assimilation during the first period upon arrival. The assimilation process seems to be exhausted after 10 to 15 years in the country, however, at which point there remain considerable employment and earnings gaps relative to natives. And following the initial period of labor market assimilation, social insurance dependency appears to rise rather inexorably with years since arrival even for these immigrant groups.

In the even longer term, the fiscal implications of immigration also hinge on lifecycle labor market participation of descendants of immigrants (Storesletten, 2003). Given the weak long-term labor market performance of the 1970s wave of labor migrants from low-income source countries, one might expect their children to be less successful than children of native parents. Existing empirical evidence shows large intergenerational correlations in labor market performance in general (see the review in Black and Devereux, 2011) and for immigrants in particular (Casey and Dustmann, 2008), and also a more specific tendency for social insurance dependency to spread within various kinds of social networks, including those of families (Dahl et al., 2013) and ethnic minorities (Bertrand et al., 2000; Aizer and Currie, 2004; Markussen and Røed, 2014). On the other hand, compared to their parents, the immigrant children grew up in a fundamentally different environment that may have contributed to substantial assimilation across generations. We present in this paper the first quantitative evidence on the early adulthood patterns of education, employment, earnings, and disability program participation for the children of the original labor migrant cohort from developing countries. Although it is too early to draw firm conclusions regarding lifecycle outcomes, our findings at this point show considerable convergence toward the educational attainment, employment, and earnings of natives, particularly for the second generation offspring born in Norway. Given the huge immigrant-native differentials in the parent generation, we find the more moderate differentials in the offspring generation quite encouraging. But despite the signs of improved average labor market 
outcomes in the offspring generation, we still uncover evidence of disproportionally high risks of enrollment in disability insurance programs.

\section{Immigration to Norway since 1970}

\subsection{Immigrant inflows and immigration regimes}

Between 1970 and 2014, the immigrant population of Norway, counting children of immigrant parents, increased from 1.5 to 14.9 percent of the resident population (12.4 percent if we only include those born abroad to foreign-born parents), with most of the growth coming from lowincome source countries (Statistics Norway, 2014). Figure 1 displays the counts of annual immigrant inflows between 1970 and 2012 by major source region. As the figure shows, gross inflows increased over the period from less than 10,000 to 65,000 per year, with a doubling of annual immigrant arrivals since 2004.

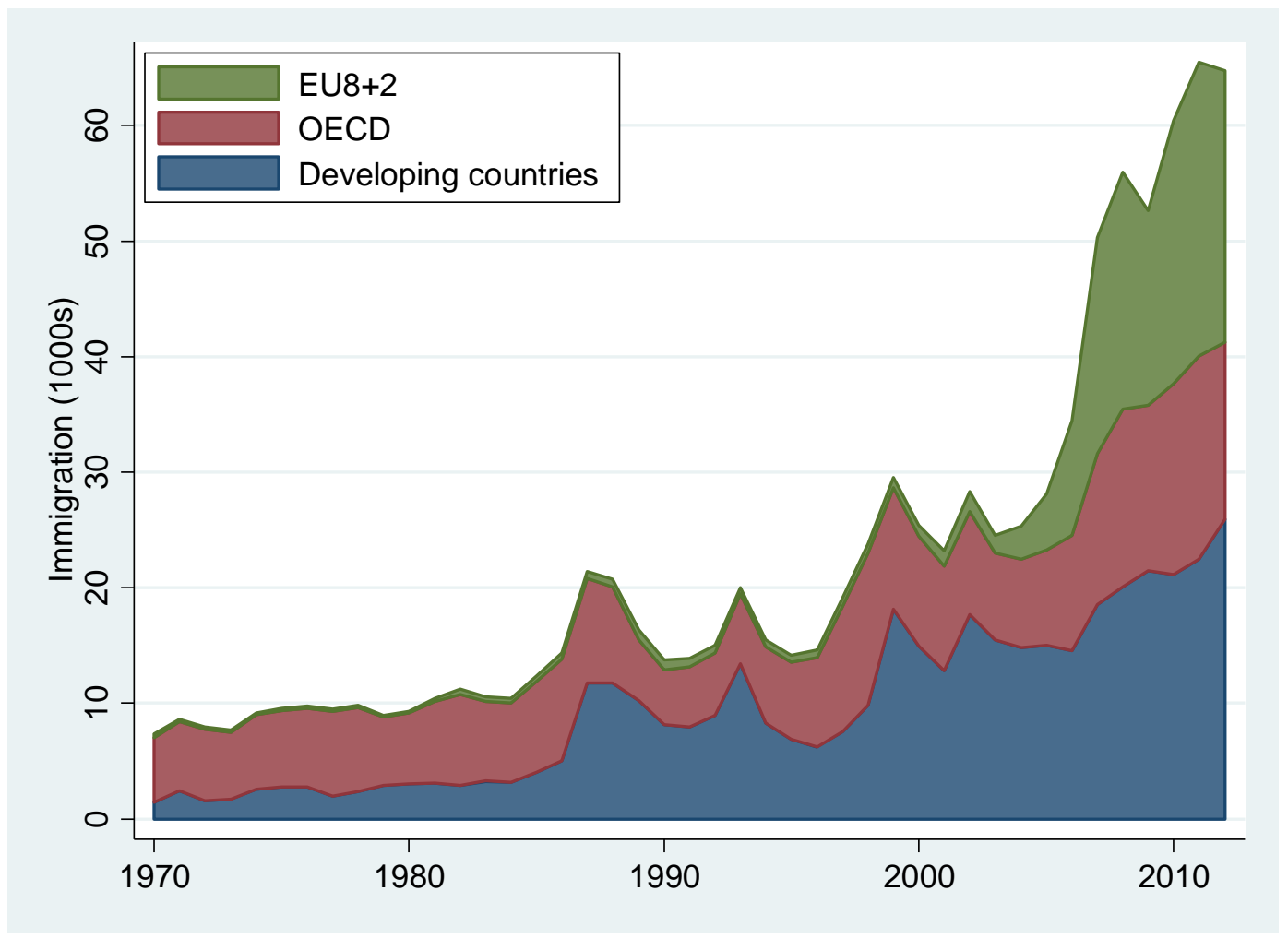

Fig 1: Immigration to Norway by major source region, 1970-2012

Note: Counts include first-time moves only. "EU8+2" group includes Bulgaria, the Czech Republic, Estonia, Hungary, Latvia, Lithuania, Poland, Romania, Slovakia, and Slovenia.

Prior to 1970, immigration to Norway chiefly consisted of Nordic citizens and other Western Europeans who either sought employment in the growing Norwegian economy or arrived because of family ties (see Brochmann and Kjeldstadli, 2008, for a comprehensive account of Norwegian immigration history). The first significant immigrant wave from developing countries in modern times 
was dominated by male labor migrants from Pakistan and Turkey who entered between 1971 and 1975, just before Norway imposed a freeze on immigration from outside the Nordic region. After the 1975 freeze, new legislation impeded labor immigration from outside Western Europe but facilitated family-based immigration. As such, although the original cohort of workers from Pakistan and Turkey was of modest size, the cohort plays an important role in Norwegian immigration history as it paved the way for substantial chain migration through family reunification and family formation. To illustrate, among the 2,405 labor migrants from Pakistan and Turkey who stayed until the 1990s (and who are included in our analyses below), 2,172 were subsequently joined by a foreign-born spouse who in 99 percent of the cases came from the same source country as the original immigrant. In the years that followed, children of the original cohort generated additional family-based immigration was as they found their spouses in their parents' source country. Through such family immigration dynamics, Pakistani-born had grown to become the largest immigrant population group in Norway by the turn of the century.

Since the 1975 immigration freeze, labor immigration from developing countries has been negligible. Between 1975 and 2004, admission to Norway from outside Western Europe was dominated by humanitarian motives (i.e., refugees and asylum seekers granted protection) and family reunification (often to immigrants admitted for humanitarian reasons). The visible spikes in Figure 1 correspond to large waves of refugee arrivals and persons granted political asylum. These waves foremost consisted of persons fleeing political unrest and war in Iran, Chile, Sri Lanka, and Vietnam (1980s), the Balkans (early 1990s), and Iraq and Somalia (late 1990s).

The immigration legislation gives citizens of countries with a labor agreement with Norway the right to enter the country and search for a job for up to six months. Important labor agreements in recent times include those between the Nordic countries since 1954 and the European Economic Area (EEA; i.e., the European Union and member states of the European Free Trade Association) since 1994. For citizens of other countries, work-related admission is available through the "specialist" or "seasonal worker" programs. Both channels normally require that the applicant already has a job offer in hand. Although Norway has stayed outside the European Union, the 2004 and 2007 eastwards enlargements of the European Union opened the Norwegian labor market to citizens of accession countries owing to Norway's EEA membership. As is evident from Figure 1, the EU enlargement triggered a major wave of labor immigration to Norway that accounts for the majority of the rise in immigration since 2004.

\subsection{Selection of immigrant arrival cohorts to study}

In the empirical analyses below, we examine the long-term labor market and social insurance outcomes of immigrants in Norway. We seek to describe the long-term assimilation processes of groups that are representative of the major source countries of the immigrant population as well as the various immigration regimes since 1970. At the same time, our main objective is to study the developments of immigrant outcomes with time in the host country, and a key methodological feature is to take advantage of our access to longitudinal records from comprehensive administrative register data and track the labor market and social insurance outcomes of individuals as they age. For such reasons, we focus on immigrants who arrived as young adults from the major source countries within each immigration regime. We further focus on the five-year arrival interval with the highest representation of individuals aged 17-36 at entry. The narrowly defined arrival cohorts will reduce 
heterogeneity in outcomes linked to variation in economic conditions or institutional arrangements at the time of entry (Åslund and Rooth, 2007).

The selected arrival cohorts are detailed in Table 1. The cohorts include the original group of male labor migrants who arrived from Pakistan and Turkey during the early 1970s. To complete the picture of potential fiscal consequences of labor immigration, we also examine immigrants from rich OECD countries and study young males who arrived from Western Europe during the same period. And, because of the large scale, we further study labor migrants who arrived from Eastern Europe following the 2004 expansion of the European Union, focusing on the two major source countries Poland and Lithuania (that accounted for 89 percent of the inflow from the new EU members during the period). But unlike the labor migrant cohorts from the 1970s, we will not be able to describe the long-term economic outcomes of the recent Eastern European labor immigrants.

Table 1: Immigrant cohorts under study

\begin{tabular}{|c|c|c|c|c|c|c|c|}
\hline Immigrant cohort & $\begin{array}{l}\text { Typical } \\
\text { admission } \\
\text { class }\end{array}$ & $\begin{array}{c}\text { Cohort } \\
\text { size }\end{array}$ & $\begin{array}{c}\text { III } \\
\text { Percent } \\
\text { in } \\
\text { Norway } \\
\text { at least } 5 \\
\text { years } \\
\end{array}$ & $\begin{array}{c}\text { IV } \\
\text { Observa- } \\
\text { tions in } \\
\text { analysis } \\
\text { sample }\end{array}$ & $\begin{array}{c}\text { Median } \\
\text { age at } \\
\text { arrival }\end{array}$ & $\begin{array}{c}\text { Com- } \\
\text { pleted } \\
\text { upper } \\
\text { 2nd educ }\end{array}$ & $\begin{array}{c}\text { VII } \\
\text { Com- } \\
\text { pleted } \\
\text { upper } \\
\text { 2nd, } \\
\text { native ref }\end{array}$ \\
\hline \multicolumn{8}{|l|}{ A. Men } \\
\hline Western Europe 1971-75 & Work & 8,288 & 41.3 & 84,714 & 25 & 67.4 & 46.6 \\
\hline Pakistan/Turkey 1971-75 & Work & 2,943 & 90.2 & 84,237 & 25 & 32.9 & 45.4 \\
\hline Pakistan/Turkey 1986-90 & Family & 2,318 & 80.1 & 35,125 & 25 & 37.5 & 64.1 \\
\hline Refugees 1986-90 & Refugee & 7,982 & 91.8 & 146,618 & 25 & 62.2 & 63.7 \\
\hline Balkans 1991-95 & Refugee & 3,791 & 77.6 & 48,406 & 27 & 77.1 & 67.8 \\
\hline Refugees 1996-2000 & Refugee & 5,205 & 85.6 & 49,827 & 28 & 50.7 & 74.5 \\
\hline New EU 2004-07 & Work & 13,255 & 77.4 & 54,402 & 29 & 83.2 & 76.7 \\
\hline \multicolumn{8}{|l|}{ B. Women } \\
\hline Western Europe 1975-79 & Work/fam & 8,971 & 37.0 & 79,439 & 25 & 78.2 & 35.6 \\
\hline Pakistan/Turkey 1975-79 & Family & 1,187 & 91.6 & 32,637 & 24 & 18.4 & 35.6 \\
\hline Pakistan/Turkey 1986-90 & Family & 1,511 & 95.0 & 28,670 & 23 & 23.7 & 65.4 \\
\hline Refugees 1986-90 & Refugee & 4,181 & 91.9 & 77,087 & 26 & 58.3 & 57.2 \\
\hline Balkans 1991-95 & Refugee & 3,157 & 82.1 & 43,797 & 28 & 70.2 & 65.4 \\
\hline Refugees 1996-2000 & Refugee & 2,348 & 92.2 & 25,181 & 27 & 37.0 & 76.2 \\
\hline New EU 2004-07 & Work/fam & 4,957 & 85.5 & 22,309 & 27 & 88.1 & 83.2 \\
\hline
\end{tabular}

Note: Immigrant cohorts consist of those aged 17 to 36 at the time of arrival. Completed upper secondary education is conditional on non-missing education data; educational attainment is missing for 8 percent of the pre-2004 arrivals, but for 38 percent of men and 24 percent of women in the "New EU 2004-07" cohort. Native educational attainment is shown for the median birth cohort of the respective immigrant sample.

In addition to the original group of male labor migrants, we examine long-term outcomes of three five-year arrival cohorts of subsequent immigrants from Pakistan and Turkey. The three cohorts consist of women who arrived between 1975 and 1979 (typically wives of the original labor immigrant cohort), as well as men and women who arrived between 1986 and 1990-15 years after the original cohort (typically close relatives like siblings or children-in-law arriving on a family 
reunification visa). These three groups form the basis for our longitudinal studies of labor market integration of family-based immigrants from developing countries.

The study cohorts further cover three waves of refugee arrivals. We have chosen to focus on the main source countries of waves that are of sufficient size over relatively short entry periods to make a "cohort study" meaningful. These humanitarian immigrant cohorts came from (i) Chile, Iran, Somalia, Sri Lanka, and Vietnam (table and figure label, "Refugees 1986-90"); (iii) Bosnia and Kosovo (“Balkans 1991-95"); and (iv) Iraq and Somalia ("Refugees 1996-2000").

To avoid the confounders caused by compositional change, in the longitudinal analyses we consider employment, earnings, and welfare participation among members of the various immigrant cohorts who stayed in Norway over the long term. In order to apply the same sample inclusion requirement across the various arrival cohorts, we follow Sarvimäki (2011) and limit the analyses to those who remained in Norway for at least five years. Table 1, column III, shows the percent of each arrival cohort who stayed for five years or more, and who form the basis for the longitudinal analyses of the next sections. The column highlights the variability in outmigration behavior across origin countries; while the vast majority of immigrants from low-income source countries stay in Norway over the long haul, most of the immigrants from high-income countries end up returning to their source country.

The longitudinal data allow us to follow individual immigrants through 2012, i.e., for 40 years after arrival for those who arrived during the early 1970s. We exclude observations the year of arrival, and include in the analyses only years when the immigrant actually is present in Norway. We further restrict the analyses of labor market and social insurance outcomes to those aged 25-64 in the observation year. Column IV reports the size of the resulting analysis samples. As column $\mathrm{V}$ shows, the typical age of arrival is 25 , with modest variation across the immigrant groups. The various immigrant cohorts differ considerably in their educational attainment, though, with high-school completion rates ranging from below 20 percent among the 1970s female immigrants from Pakistan and Turkey to above 75 percent for 1970s females from Western Europe; see col VI. (The column indicates even higher completion rates among recent immigrants from Eastern Europe, but unfortunately data on attainment is missing for a large fraction of this sample; see table note.) The great variability in formal qualifications is expected to generate considerable labor market performance differences across immigrant groups. Finally, to provide a comparative perspective, we have also included in the table completion rates for natives born in the median birth year of the respective immigrant sample; see col VII. These numbers illustrate the dramatic increase in native educational attainment over time, with completion rates from upper secondary school rising for women from 36 percent of the early 1950s birth cohorts to 83 percent of those born around 1980.

Because we study immigrants who stayed in Norway at least five years in order to reduce any bias caused by selective return migration, we emphasize that our analysis is not designed to be representative for a given arrival cohort. In section 3.3 we discuss differences in early labor market outcomes between those who later outmigrated and those who stayed in Norway. When we compare their short-term economic successes, the data give examples of both positive and negative selection in return migration and there is no clear indication that our focus on those who stay for the long haul results in a biased picture of the long-term assimilation processes of immigrants. 


\section{Institutional setting and trends in labor market performance}

In any comparison of labor market performance across groups, the question arises of whether the observed variation in outcomes should be adjusted for differences in skills and other relevant characteristics. From a pure net public transfer perspective of the host country, unconditional immigrant performance measures are the most relevant metric. But when we study mechanisms, selection, and assimilation processes, the focus is on immigrant performance relative to comparable natives and the more appropriate statistic controls for differences in human capital and other determinants of labor market success. In this paper, we present evidence from both perspectives. Based on data drawn from linked administrative registers, we first provide a brief overview of the labor market performance and social insurance utilization of the arrival cohorts described in the prior section. While we for now examine purely descriptive patterns - with calendar year as the time unit of interest - in the next section we turn to regression-based analyses of assimilation processes relative to natives with years since migration (YSM), and condition individual outcomes on educational attainment and family characteristics.

Throughout the analyses, we focus on annual outcomes describing employment and earnings, on the one hand, and social insurance claims and disability program participation, on the other. But before we address how the various immigration cohorts have performed in the labor market over time, we provide some institutional background in relation to the social insurance system.

\subsection{Social insurance institutions}

The major social insurance programs in Norway are universal and financed through general taxation. During the 40-year period covered by our longitudinal analyses, there have been some adjustments to basic parameters such as eligibility criteria, maximum duration regulations, and replacement ratios. But the key features of the system have remained stable over time, and in this subsection we give a brief overview of its main elements. For most programs eligibility is based on individual labor earnings in recent years, although some programs are means tested at the household level. Immigrants and natives are in general treated equally, as nationality and years of residence are irrelevant once other criteria (such as those related to past earnings) are met. ${ }^{1}$

In short, the Norwegian social insurance programs can be divided into four main categories:

- Unemployment insurance: The unemployment insurance program is available for active job seekers who have lost their job involuntarily. To be eligible, job seekers must have had labor earnings exceeding 1.5 times the social insurance base amount ("1.5G," presently 123,183 NOK or $€ 16,500$ ) during the past calendar year or earnings of at least $3 \mathrm{G}$ over the three calendar years prior to unemployment entry. The replacement ratio in the unemployment insurance program is 62.4 percent (but with lower and upper bounds on benefits), and the maximum duration is currently two years. Under normal business cycle conditions, the unemployment insurance caseload comprises around 2-3 percent of the labor force.

- Sickness pay: Sickness pay is available for employees who are absent from work due to a health problem (certified by a physician). The social insurance system offers a $100 \%$ replacement ratio up to a ceiling of $6 \mathrm{G}$ (presently 492,732 NOK or $€ 66,000$ ) from the $16^{\text {th }}$ to

\footnotetext{
${ }^{1}$ An exception is labor migrants from new EU member countries who, during a five-year transitional period following accession, were not entitled to unemployment insurance during the first 12 months in Norway.
} 
the $365^{\text {th }}$ day of absence. The caseload normally comprises around 4-5 percent of all employees.

- Disability insurance and rehabilitation: Disability insurance is designed to secure income for persons with reduced work capacity due to sickness or injury. The temporary disability insurance (TDI) program offers a replacement ratio around $66 \%$ of presumed forgone earnings, as well as supplementary benefits for dependent children. A benefit floor of $2 \mathrm{G}$ (presently 164,244 NOK) ensures progressivity at low earnings levels. Eligibility requires that work ability is reduced by at least 50 percent. Participants are typically individuals who have exhausted their one-year sickness pay entitlements, but the program is also available to those who have not been employed at all (in this case the benefit level is set to the floor of 2G). TDI can presently be paid out for up to four years, but during most of the period covered by our analysis there were no explicit maximum duration. The program normally entails medical and vocational rehabilitation attempts. The TDI caseload is currently around 5-6 percent of the working-age population. Permanent disability insurance (PDI) is typically granted after several years on TDI, and an important entry condition is that vocational rehabilitation has been tried first (unless deemed to be obviously futile). This program offers similar replacement ratios as the temporary disability insurance program, but no time limit and no rehabilitation requirement. The PDI caseload is 10-11 percent of the working-age population. Although entitlement to disability insurance benefits requires that a person's work capacity is reduced due to sickness or injury, prior research shows that there is a large grey area between unemployment and disability, and that a significant fraction of disability insurance claims are triggered by job loss; see, e.g., Rege et al. (2009) and Bratsberg et al. (2013). The Norwegian legislation also explicitly states that the social insurance administration may consider the employment opportunities of the applicant when ruling whether or not the loss of work capacity is sufficiently large to qualify for disability benefits.

- Social assistance (welfare): Social assistance is means tested against family earnings and wealth. It is provided by the municipalities typically to persons who have no or very low labor earnings and who are ineligible for unemployment and disability insurance.

In addition to these major income replacement programs, there are also programs for transitional lone parent support and general cash subsidies to families with children.

With respect to the immigrant arrival cohorts under study, it is important to emphasize that the empirical relevance of each program will vary across groups according to admission class and with years since migration. Labor immigrants are - by definition - employed at the time of entry and therefore also typically non-disabled. In the event of job loss, they will normally be entitled to unemployment benefits, just like natives. ${ }^{2}$ In the event of disability, they will almost immediately qualify for sickness pay and subsequent temporary disability insurance, whereas permanent disability insurance will not be relevant until they have been in Norway for several years. Since labor

\footnotetext{
${ }^{2}$ Because eligibility depends on earnings during the prior one to three calendar years, entitlement to UI benefits will normally apply from the second year of employment. Since 2007, labor immigrants from the European Economic Area are entitled to unemployment benefits immediately upon employment in Norway, provided that they can document earnings from their home country corresponding to the Norwegian eligibility requirements (after adjustments for general wage differentials between the two countries).
} 
immigrants are typically of good health at the time of entry, we expect in any case to see little use of disability insurance during their first years in the country.

Refugees and asylum seekers are typically not employed at the time of arrival, and they have not had time to build up entitlements for programs with eligibility based on past labor earnings. Some of these humanitarian immigrants are thus likely to be reliant on social assistance in the beginning of their stay. ${ }^{3}$ After some time in the country, other insurance programs may take over, depending on employment experiences and health status.

\subsection{Employment and earnings}

Figures 2 and 3 display trends in employment and earnings for the immigrant arrival cohorts under study. The left-hand-side panels present data for men, the right-hand-side panels data for women; the upper panels present data for the various labor migrant cohorts and their families, the lower panels data for humanitarian immigrant cohorts (see Section 1 for details). To place the immigrant profiles in perspective, we have added the corresponding average outcome for native men or women of working age (25-64 years) to each panel.

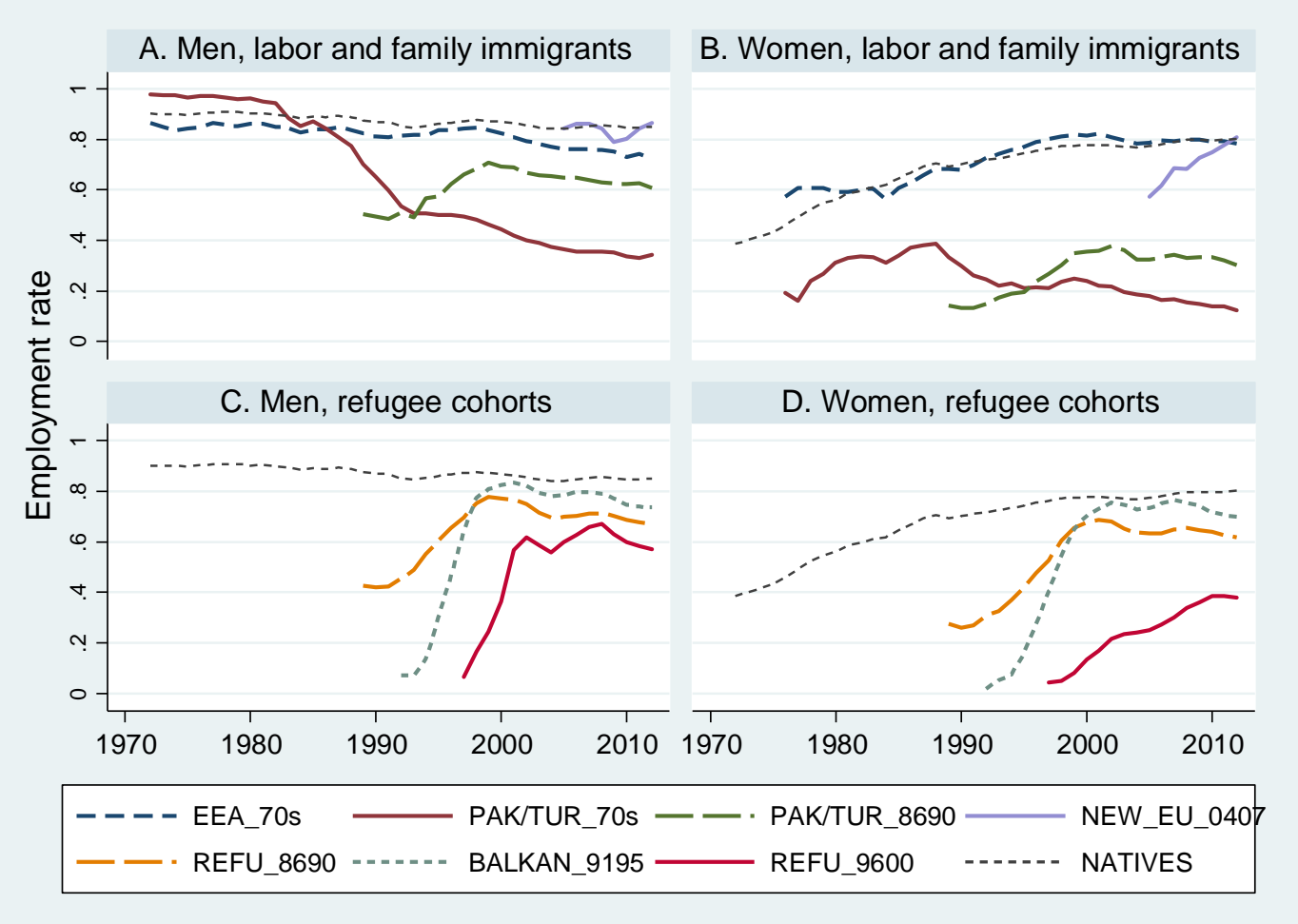

Figure 2: Trends in employment, immigrant cohorts and natives, 1972-2012.

Note: The data cover those aged 25-64 and present in Norway the full calendar year.

\footnotetext{
${ }^{3}$ In 2004, a separate "introduction program" was introduced for humanitarian immigrants to Norway, ensuring economic support during the first years of stay, but this program is not relevant for the cohorts studied in this paper.
} 
The earnings data underlying the figures are drawn from the registers of the tax authority and correspond to total reported labor earnings in each year, including self-employment earnings, and are inflated to 2012 values by the consumer price index (CPI). These data are available throughout the time period relevant for our immigrant cohorts; i.e., from the early 1970s through 2012. The employment numbers in Figure 2 are constructed from these earnings records, so that individual employment in a certain calendar year is defined as having annual labor earnings above the base amount ("G") of the national social insurance program, currently equal to NOK 82,122 or approximately $€ 11,000$ (annual earnings of $1 \mathrm{G}$ is the lower threshold for earning pension points in the national pension scheme). By using this definition of annual employment, rather than, for example, base it directly on employee registers, we ensure that the measure covers self-employed but avoid including jobs of negligible economic significance. Our earnings threshold is low, though, approximately one sixth of the average level of full-year-full-time earnings. It is also notable that the employment figures generated by this measure match quite well with the employment numbers from Statistics Norway's regular labor force sample surveys.

Looking first at the data for all natives of working age, we see from Figure 2 that male employment declined slightly over the 40-year period covered. Female labor force participation has increased dramatically as the employment rate doubled over the same period, with particularly large increases during the 1970s and 1980s. Norway has experienced a rather spectacular rise in real earnings over the 40-year period, as shown in Figure 3. Real earnings have doubled for men, despite the small decline in the employment rate, and more than tripled for women, partly reflecting their increased labor force participation. The growth in real earnings has been relatively stable over time, with the exception of the economic slumps of the early 1980 s and early 1990 s as well as during the financial crisis.

Moving on to the cohorts of labor and family immigrants (see Figures 2 and 3, Panels A and B), we first note that the European immigrants of the 1970s have performed similarly to the native average throughout the sample period. Female EEA immigrants have even had considerably higher earnings than native women. In contrast, for the cohorts from developing countries both employment and earnings trajectories tend to lie well below those of natives. For the early labor immigrants from Pakistan and Turkey, the picture is particularly worrying. While these labor migrants had high employment rates and earnings during the 1970s, they have since experienced a steep decline and toward the end of the observation period less than 40 percent of those working aged remained in employment and their earnings were one third of the native average. Looking at the most recent wave of labor migrants from the new EU member countries after 2004, the figures show that male employment rates in general are similar to those of native men, whereas female employment rates start at a somewhat lower level but rapidly catch up with those of native women. The employment figures for men indicate particular vulnerability to business cycle fluctuations; the employment rate fell from 86 percent prior to the financial crisis to 79 percent in 2009. While employment rates among migrants from the new EU member countries are generally high for both genders, average earnings fall significantly short of those of natives.

For chain migrants from Pakistan and Turkey admitted through family unification or family formation during the 1970s and 1980s, the profiles display significant lifecycle employment and earnings gaps relative to natives. Even if employment rates improved during the 1990 s, the convergence stagnated 
at levels considerably lower than natives. Female family migrants had particularly low earnings throughout (see Figure 3, Panel B).

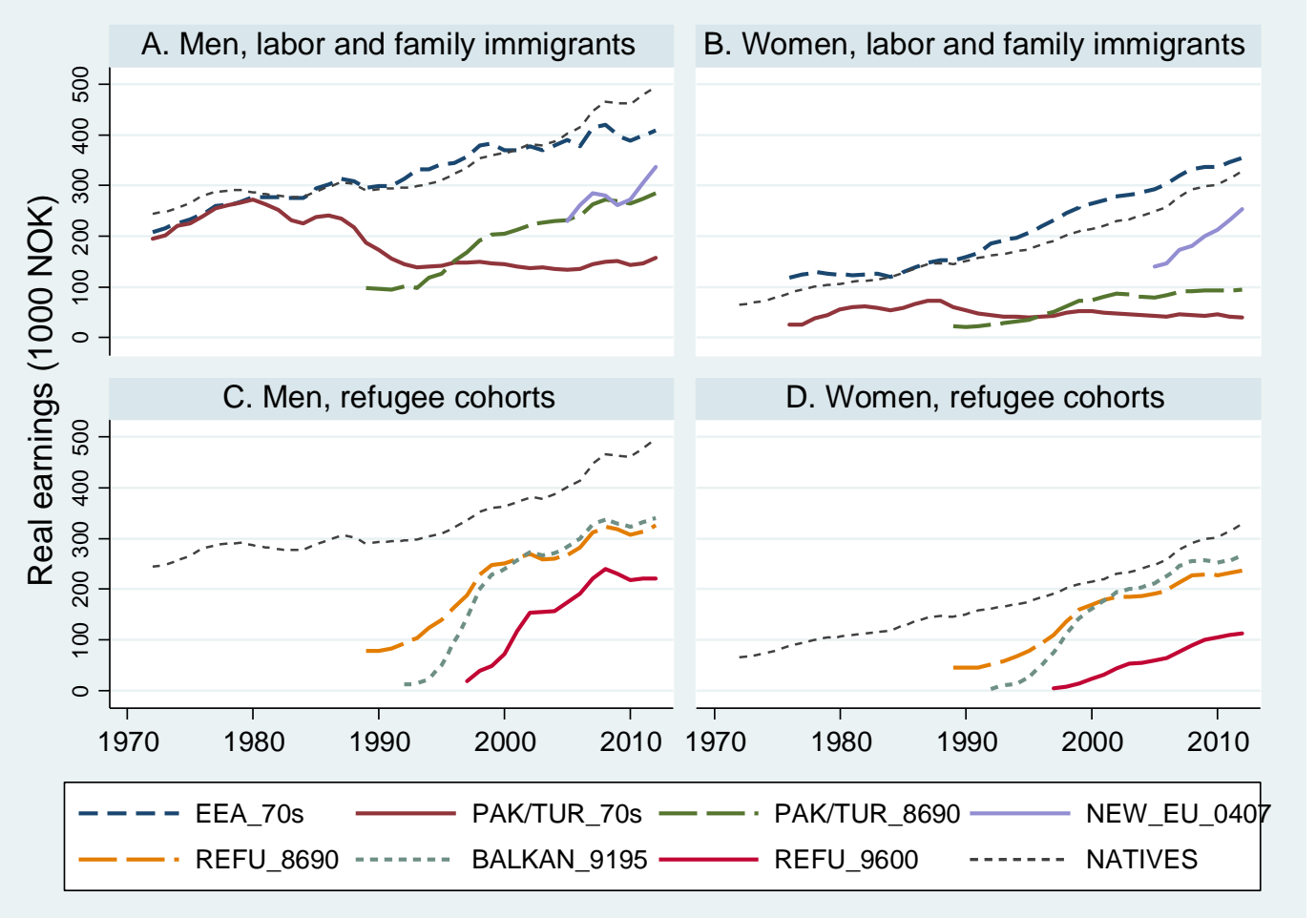

Figure 3: Real annual labor earnings measured in 1000 NOK (adjusted to 2012 value with the consumer price index), immigrant cohorts and natives, 1972-2012. Not conditioned on employment.

Note: Depicted averages are for those aged 25-64 and present in Norway the full calendar year.

For the humanitarian immigrant cohorts, the picture is more mixed (Figures 2 and 3, Panels C and D). Even though employment and earnings started out at a very low level upon arrival, the profiles reveal rapid convergence toward native employment levels during the 1990s and further convergence in earnings during the early 2000s. For refugees arriving in the late 1990s, the labor market assimilation process seems to halt much earlier and at a lower level than for the earlier refugee cohorts.

\subsection{Social insurance claims and disability program participation}

We also consider outcomes representing the degree of social insurance dependency. These data are available at the individual level starting in 1992, and cover receipts from all of the major social insurance programs, including unemployment insurance, sickness benefits, disability insurance, social assistance, and transitional lone-parent support. Since the program composition of social insurance claims is likely to vary significantly with years since arrival - for purely institutional reasons (see Section 2.1) - we first focus on the overall level of transfer earnings regardless of program, and simply add up all transfers from the welfare state during the calendar year, and inflate them to 2012 values using the CPI (see Figure 4). 
In addition, we examine more closely participation in the disability insurance programs, as these are by far the quantitatively most important and costly programs, particularly from a long-term perspective. We have chosen to include all disability-related programs into one category labelled disability program participation (see Figure 5 ). This measure is chosen because classification of individuals across, for example, the temporary and permanent disability insurance programs has varied over time, and because the administrative process ending in permanent disability insurance is typically so long (often 5-10 years after the onset of disability) that it almost by definition is irrelevant for immigrants during their first decade in Norway.

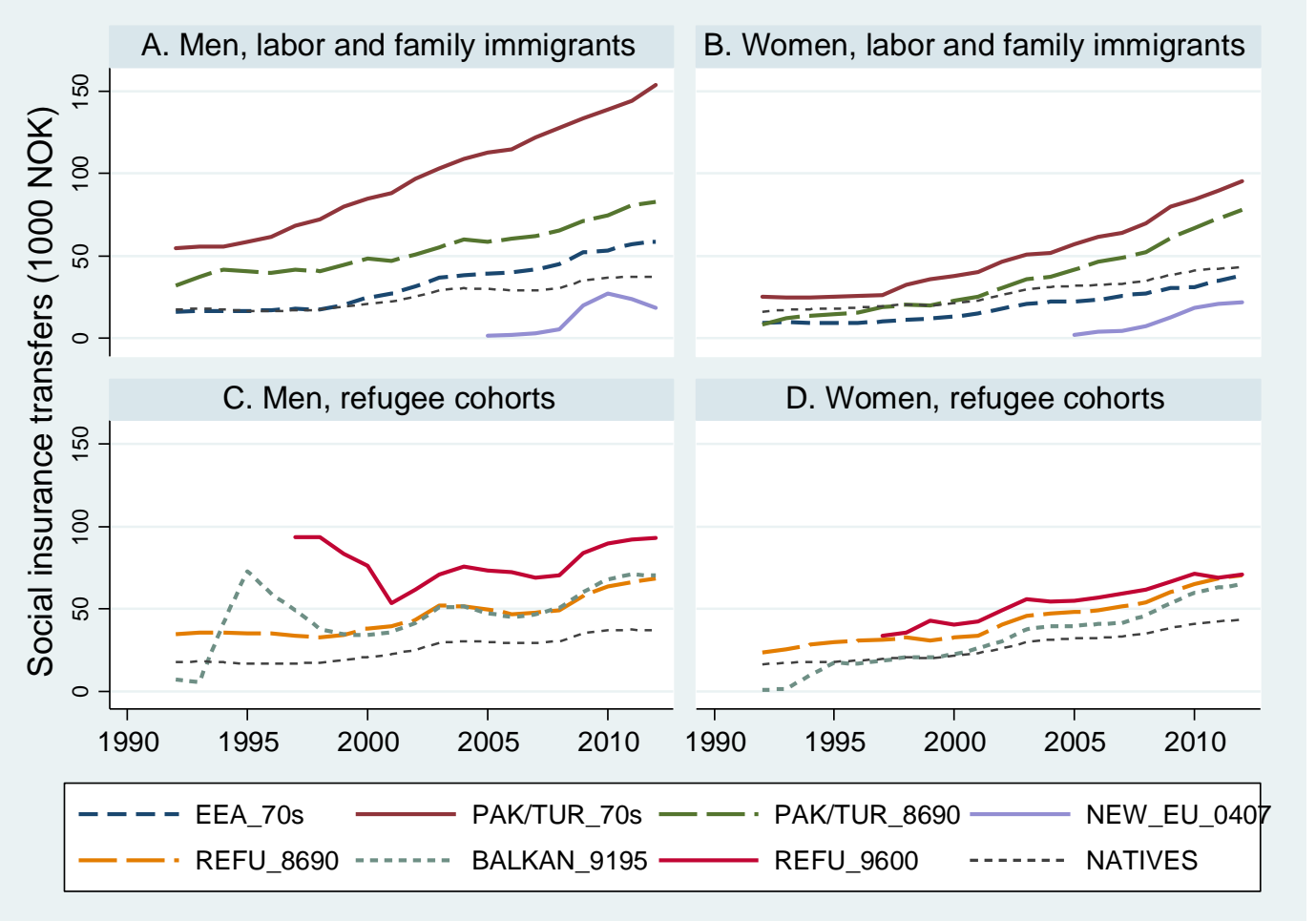

Figure 4: Annual social insurance transfers in 1000 NOK (adjusted to 2012 value with the consumer price index), 1992-2012.

Note: Social insurance transfers include receipts of unemployment insurance, sickness benefits, disability insurance, social assistance, and transitional lone-parent support. Depicted averages are for those aged 25-64 and present in Norway the full calendar year.

Together, Figures 4 and 5 provide overviews of the immigrant cohorts' total social insurance claims and of their participation rates in disability insurance programs, along with annual averages for the native working-age population for comparison. These graphs indicate an important role of social insurance in explaining employment trajectories of immigrants in Norway. Again, there are relatively minor differences between European immigrants of the 1970s and natives. For the early labor migrants from Pakistan and Turkey, however, we observe a dramatic rise in social insurance dependency over time. In 2012, these labor migrants received on average 154,000 NOK $(€ 20,500)$ in 
social insurance transfers, and as many as 62.5 percent claimed a disability insurance benefit (see Figures 4 and 5, Panel A). A similar - though perhaps less dramatic - pattern is observed for their spouses and subsequent family migrants. For the humanitarian immigrant cohorts, we see as expected relatively high transfer levels during the first period upon entry. Such early transfers are dominated by temporary income support programs, and following some decline after the initial period there is a concerning pattern of rising social insurance receipts over time. And as shown in Figure 5, Panels $C$ and $D$, an important explanation for this pattern is a sharp increase in the fraction claiming disability benefits.

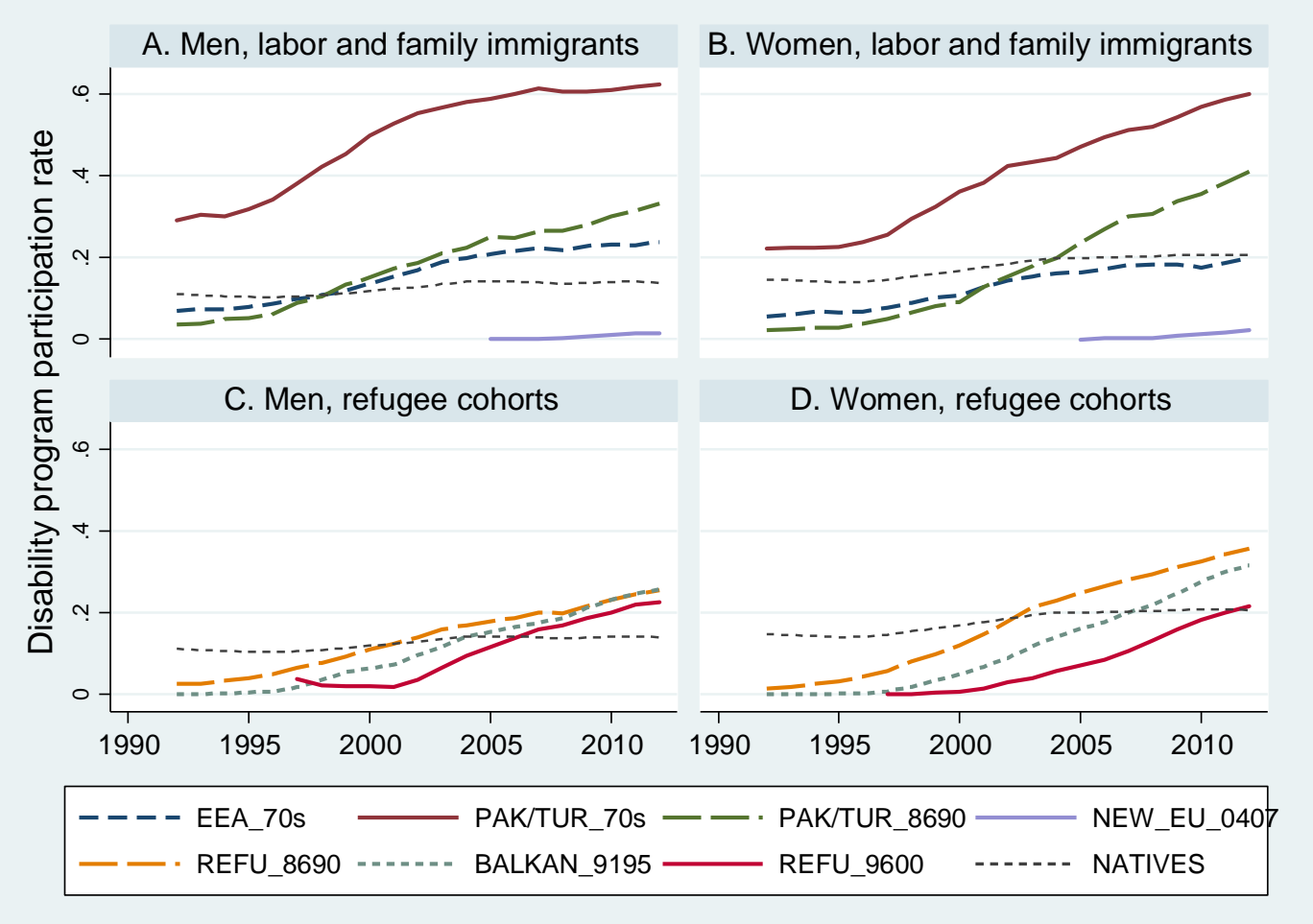

Figure 5: Disability program participation among immigrants and natives, 1992-2012.

Finally, for the most recent cohort of Eastern European labor migrants, we note that they received no transfers at all during the first years after arrival, but that transfers rose markedly in $2008 / 2009$. As we return to in Section 4, this rise reflects unemployment benefits during the financial crisis, which hit Eastern European immigrants particularly hard (partly owing to their concentration in the highly cyclical construction industry). As can be seen from Figure 5, the recent Eastern European labor migrants have not (yet) made it onto the disability insurance rolls.

\subsection{Mechanisms}

The longitudinal labor market performance profiles presented in this section paint a quite heterogeneous picture of the long-term fiscal consequences of immigration. An important factor behind the dissimilarity of experiences is of course variation in the composition of the immigration cohorts, particularly in terms of age, human capital, and family situation. Moreover, the various 
cohorts have arrived under different personal circumstances, with diverse motives for migration, and experienced different cyclical conditions. In the next section, we seek to identify the underlying assimilation processes by looking at how performance differentials between the various immigrant cohorts and natives develop with years since migration when we control for age, educational attainment, family characteristics, and calendar time (cyclical fluctuations). Ideally, we would have liked to account for a wider set of skills at the time of entry, including pre-migration work experience, language proficiency and reading capacity, as well as health status. Cultural values and attitudes add to these unobserved characteristics which may explain differences in labor market performance within and across groups.

\section{Long-term labor market and social insurance assimilation}

\subsection{Empirical framework}

To study the immigrant assimilation processes in the labor market and social insurance system, we use an empirical model that builds on the framework of Borjas $(1985 ; 1995)$. Suppose the outcome (e.g., log earnings) equation of immigrant group / observed in calendar year $t$ is given by ${ }^{4}$

$$
y_{j t}=X_{j t} \phi^{I}+\delta^{I} A_{j t}+\alpha^{I} Y S M_{j t}+\sum_{s} \gamma_{s}^{I} \Pi_{j s}+\varepsilon_{j t}
$$

and the outcome equation of natives by

$$
y_{j t}=X_{j t} \phi^{N}+\delta^{N} A_{j t}+\sum_{s} \gamma_{s}^{N} \Pi_{j s}+\varepsilon_{j t}
$$

where $y_{j t}$ is the outcome of person $j$ in year $t ; X$ is a vector of socio-economic characteristics (such as educational attainment); $A$ gives the age of the individual at the time of observation; YSM is the number of years the immigrant has resided in the host country; and $\Pi_{j}$. denotes a set of indicator variables set to unity if the observation is made in calendar year $t$. Within a group defined by arrival year, we have collinearity between YSM and year of observation, implying that the coefficients $\alpha^{I}$ and $\gamma^{I}$ are not separately identified. A common strategy is the restriction of equal period effects, $\gamma^{I}=\gamma^{N}$ (Borjas, 1985; 1991), where trends as well as transitory changes in aggregate macroeconomic and labor market conditions are assumed to have the same relative impact on outcomes of natives and immigrants.

The equal period effect assumption is, however, unlikely to hold as prior evidence from Norway (Barth et al., 2004), Germany and the UK (Dustmann et al., 2010), and the US (Bratsberg et al., 2006) show that immigrant wages (and employment) are more procyclical than those of natives. Here we take two strategies to account for differential business cycle effects across groups. First, we include in the empirical model a full set of interact terms between indicators for educational attainment and year of observation, so that period effects differ by attainment. Second, in the log earnings equation we follow Barth et al. (2004) and include the logarithm of municipal unemployment and allow for differential wage curve elasticities for natives and each immigrant group.

\footnotetext{
${ }^{4}$ To simplify the notation, higher-order terms of age and YSM are omitted here. The empirical model includes a quartic polynomial of age and a cubic polynomial of YSM.
} 
Based on the set of jointly estimated coefficients from equations (1) and (2) we predict outcome profiles from age 25 (corresponding to the median age at arrival) onwards, which for immigrant group I reads

$$
\widehat{y^{I}}=\overline{X_{I}} \phi^{I}+\widehat{\delta^{I}}(A-25)+\widehat{\alpha^{I}} Y S M, \quad Y S M=A-25=1, \ldots, \min (\max Y S M, 30),
$$

and for natives

$$
\widehat{y^{N}}=\overline{X_{N}} \phi^{N}+\widehat{\delta^{N}}(A-25), \quad A=26, \ldots, 55
$$

We plot the difference for relevant values of YSM as

$$
\widehat{y^{I}}-\widehat{y^{N}}=\overline{X_{I}}\left(\widehat{\phi^{I}}-\widehat{\phi^{N}}\right)+\left(\widehat{\delta^{I}}-\widehat{\delta^{N}}\right)(A-25)+\widehat{\alpha^{I}} Y S M
$$

With the restriction of equal returns to socioeconomic characteristics (such as education) the difference equation simplifies to

$$
\widehat{y^{I}}-\widehat{y^{N}}=\left(\widehat{\delta^{I}}-\widehat{\delta^{N}}\right)(A-25)+\widehat{\alpha^{I}} Y S M
$$

Relevant control variables to be included in the $X$-vector will depend on the type of analysis. As our interest lies in comparing performance measures across immigrants groups with different skill distributions, we present outcome differentials relative to natives conditional on educational attainment and indicators for marital status and number of children under 18. Next we therefore turn to predicted differences between the various immigrant arrival cohorts and natives as they evolve with years in the host country. These analyses are based on pooled data of the immigrant samples described in Table 1 and, for computational reasons, a ten-percent random extract of the native (i.e., native born with two native-born parents)population during the observation window, 1972-2012. We consider three outcome measures: (i) employment during the observation year, (ii) log annual earnings if employed, and (iii) participation in disability insurance programs. For each outcome and each arrival cohort, we display the evolution of predicted differences vs natives in separate figures, and report predicted differentials along with their standard errors evaluated at 5 , 15 , and 25 (whenever applicable) years since migration in accompanying tables. ${ }^{5}$

\subsection{Results}

Figure 6 displays, separately for men and women, the predicted employment differences with years since arrival, based on equation (3), between each of the seven immigrant groups and natives. As "years since arrival" runs from zero, age runs from 25 for both immigrants and natives along the horizontal axis. The vertical axis gives the difference in employment shares, with a value of -.20 denoting an employment gap between immigrants and natives of 20 percentage points. Table 2 reports predicted differentials with standard errors for selected years since arrival.

\footnotetext{
${ }^{5}$ In these tables, we do not consider predicted differentials outside the observed range of YSM for the full arrival cohort. Because our final observation year is 2012 , we only report differentials evaluated at YSM=5 for the most recent arrival cohort (2004-2007). For the same reason, "15-year" entries for the 1996-2000 cohort are evaluated at $\mathrm{YSM}=12$. For all other arrival cohorts, entries correspond to the column header.
} 


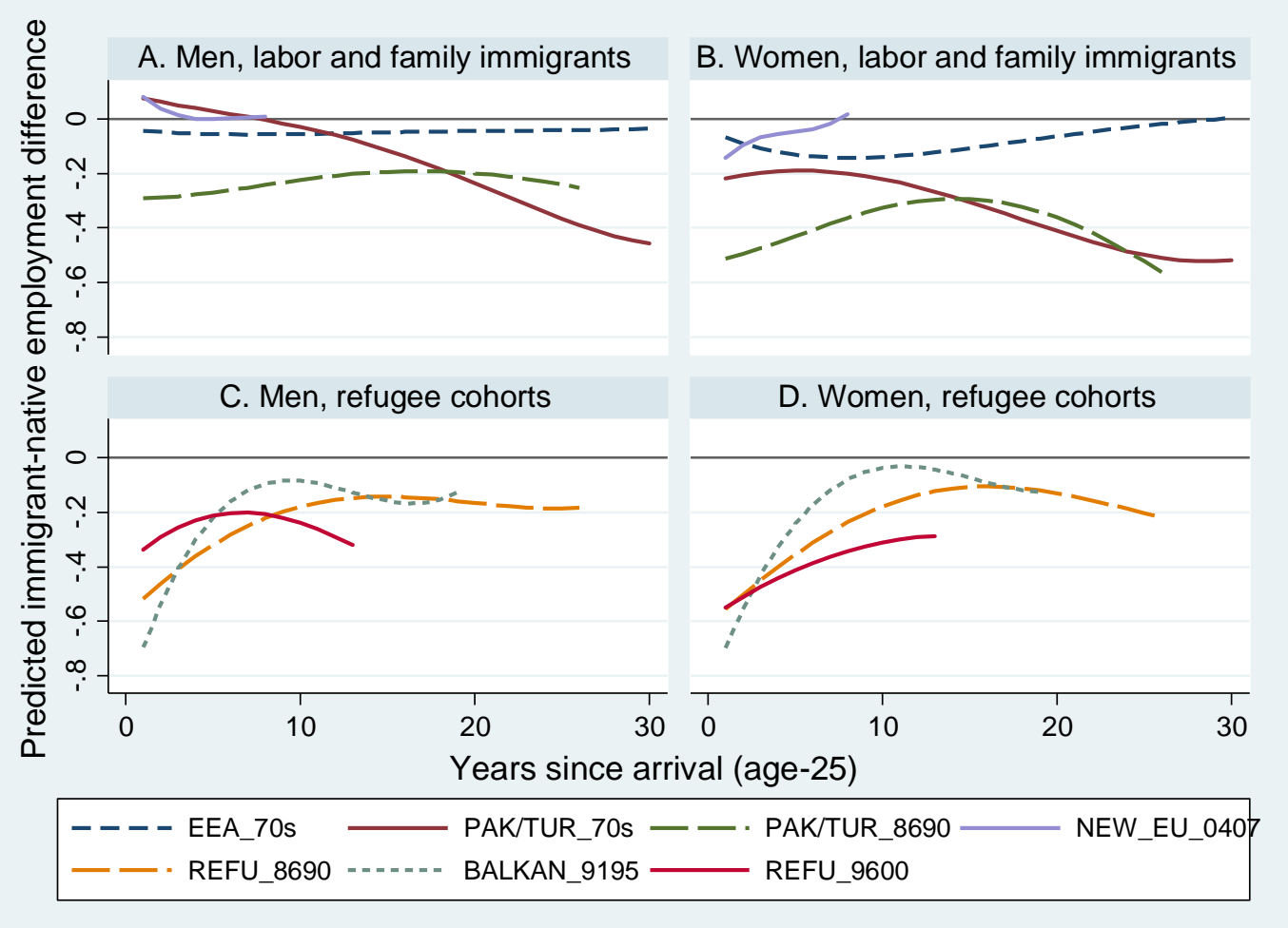

Figure 6: Predicted difference in the employment rate of immigrants and natives.

Table 2: Predicted immigrant-native employment differentials

\begin{tabular}{lccc|ccc}
\hline & \multicolumn{3}{c}{ Men } & \multicolumn{3}{c}{ Women } \\
Years since arrival: & 5 & 15 & 25 & 5 & 15 & 25 \\
\hline Immigrant cohort: & & & & & & \\
EEA 1970s & $-0.056^{* * *}$ & $-0.049^{* * *}$ & $-0.041^{* * *}$ & $-0.131^{* * *}$ & $-0.107^{* * *}$ & $-0.025^{* * *}$ \\
& $(0.005)$ & $(0.005)$ & $(0.006)$ & $(0.008)$ & $(0.007)$ & $(0.007)$ \\
Pakistan/Turkey 1970s & $0.029^{* * *}$ & $-0.115^{* * *}$ & $-0.366^{* * *}$ & $-0.189^{* * *}$ & $-0.305^{* * *}$ & $-0.499^{* * *}$ \\
& $(0.004)$ & $(0.006)$ & $(0.009)$ & $(0.013)$ & $(0.011)$ & $(0.011)$ \\
Pakistan/Turkey 1986-90 & $-0.270^{* * *}$ & $-0.194^{* * *}$ & $-0.241^{* * *}$ & $-0.431^{* * *}$ & $-0.294^{* * *}$ & $-0.522^{* * *}$ \\
& $(0.009)$ & $(0.010)$ & $(0.017)$ & $(0.010)$ & $(0.011)$ & $(0.018)$ \\
Refugees 1986-90 & $-0.319^{* * *}$ & $-0.142^{* * *}$ & $-0.185^{* * *}$ & $-0.354^{* * *}$ & $-0.106^{* * *}$ & $-0.202^{* * *}$ \\
& $(0.005)$ & $(0.005)$ & $(0.008)$ & $(0.007)$ & $(0.007)$ & $(0.013)$ \\
Balkans 1991-95 & $-0.219^{* * *}$ & $-0.158^{* * *}$ & $\mathrm{~N} / \mathrm{A}$ & $-0.242^{* * *}$ & $-0.073^{* * *}$ & $\mathrm{~N} / \mathrm{A}$ \\
& $(0.007)$ & $(0.008)$ & & $(0.009)$ & $(0.009)$ & \\
Refugees 1996-2000 & $-0.211^{* * *}$ & $-0.289^{* * *}$ & $\mathrm{~N} / \mathrm{A}$ & $-0.412^{* * *}$ & $-0.292^{* * *}$ & $\mathrm{~N} / \mathrm{A}$ \\
& $(0.008)$ & $(0.009)$ & & $(0.010)$ & $(0.012)$ & \\
New EU 2004-07 & -0.001 & $\mathrm{~N} / \mathrm{A}$ & $\mathrm{N} / \mathrm{A}$ & $-0.046^{* * *}$ & $\mathrm{~N} / \mathrm{A}$ & $\mathrm{N} / \mathrm{A}$ \\
& $(0.005)$ & & & $(0.008)$ & & \\
\hline
\end{tabular}

*/***** Significant at the $10 / 5 / 1$ percent level.

Note: Standard errors, clustered within individuals, are reported in parentheses. Regression includes quartic polynomial of age; the age polynomial interacted with each immigrant cohort; cubic polynomial of years since arrival interacted with immigrant cohort; and indicators for immigrant cohort; educational attainment (5 levels); number of children (0, 1, 2, 3, 4, and 5 plus); married, spouse present; previously married; and year of observation interacted with each education level (for a total of 312 regressors). The regression samples consist of $3,813,248$ observations of 175,488 men and $3,218,430$ observations of 147,612 women. 
Consider first the immigrant-native employment differences for male labor immigrants from the early 1970s, displayed in Panel A. While the labor migrant cohort from Pakistan and Turkey had higher employment rates than natives during their first years in the country, immigrant employment declined steadily to 37 percentage points below that of natives after 25 years (see Table 2). This pattern contrasts sharply with the long-term performance of labor immigrants from Western Europe who had similar employment rates as natives throughout the 30-year interval. The cohorts of familyrelated immigrants from Pakistan and Turkey who followed during the 1980s had low employment at entry, but improved slightly over time and were on par with their sponsoring predecessors after 18 years. For these immigrant cohorts, female employment differentials were similar to those of men.

Although women from Western Europe saw lower employment than natives during their first years in the country, the difference faded over time. Employment rates among Pakistani and Turkish women were significantly below those of native women, but the lifecycle profiles display similar shapes as those of men from the same country of origin. Turning to the more recent labor migrant from Eastern Europe, male employment is very similar to that of natives throughout the relevant YSM-range. Women from Eastern Europe gradually approach the employment rates of natives and the gap is almost eliminated six years after arrival.

The employment profiles of refugee cohorts differ distinctly from those of labor immigrants. As shown in Figure 6, Panels $C$ and $D$, all three humanitarian immigrant cohorts considered start out with relatively low employment rates. But there is a strong tendency for employment to pick up during the first 10 years after arrival. While employment among male refugees of the 1980 s and males from the Balkans stabilizes at 15 to 20 percentage points below natives (see Table 2), initial convergence is followed by a growing differential for male refugees of the 1990s. Employment assimilation is stronger among refugee women than among men. But again, we find substantial differences across refugee groups. While employment among women from the Balkans was only 7 percentage points lower than for (comparable) natives 15 years after arrival, the differential was 28 percentage points for female refugees who arrived in the late 1990s.

Following a long tradition in immigrant assimilation studies, we also consider pay conditional on employment. In Figure 7 we display the predicted differentials in log annual labor earnings with the underlying parameters estimated from the subsample of employed individuals in each year. Thus the predicted profiles will reflect variation in the hourly wage, hours worked during year, and possibly also selection as the composition of the stock of employed workers may change with years since arrival. Again, Table 3 lists the predicted differentials evaluated at 5, 15 and 25 years after arrival along with standard errors.

For the labor and family immigrants from the 1970s and 1980s, the earnings differentials relative to natives show similar developments over time as the employment differentials described above. Western Europeans tend to earn slightly less than comparable natives, with female earnings fully converging to those of native women after 20 years. Eastern European labor migrants have comparable employment rates as natives, but their earnings are considerably lower with a 25 percent gap after 5 years. Eastern European women experience slightly higher earnings growth than native women, while for males the earnings differential shows no improvement over time. 


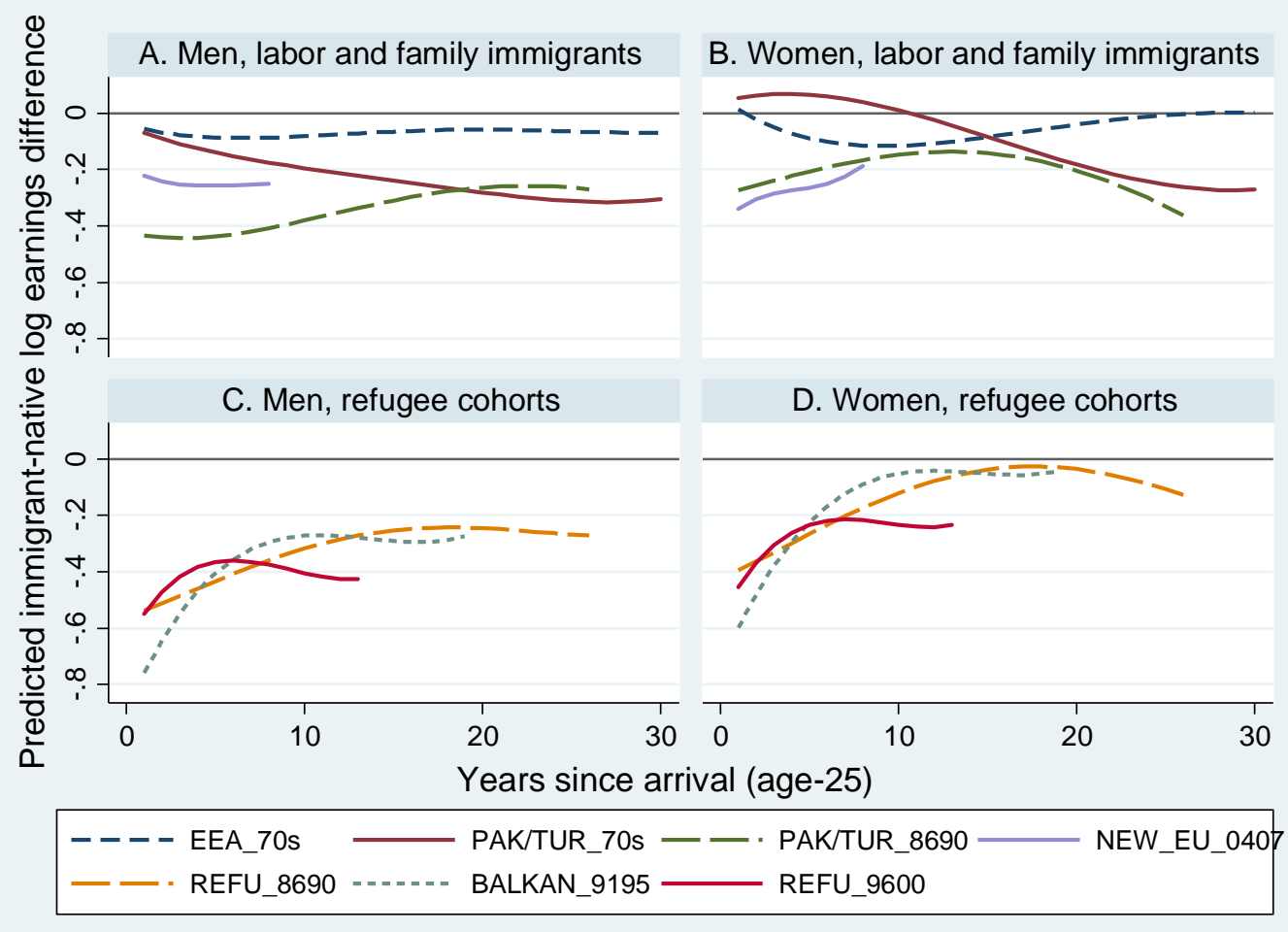

Figure 7: Log earnings among the employed. Predicted difference between immigrants and natives.

Table 3: Predicted immigrant-native log earnings differentials

\begin{tabular}{lccc|ccc}
\hline & & Men & & \multicolumn{3}{c}{ Women } \\
Years since arrival: & 5 & 15 & 25 & 5 & 15 & 25 \\
\hline Immigrant cohort: & & & & & & \\
EEA 1970s & $-0.087^{* * *}$ & $-0.066^{* * *}$ & $-0.065^{* * *}$ & $-0.089^{* * *}$ & $-0.086^{* * *}$ & -0.007 \\
& $(0.010)$ & $(0.009)$ & $(0.010)$ & $(0.010)$ & $(0.009)$ & $(0.009)$ \\
Pakistan/Turkey 1970s & $-0.140^{* * *}$ & $-0.239^{* * *}$ & $-0.312^{* * *}$ & $0.065^{* * *}$ & $-0.084^{* * *}$ & $-0.254^{* * *}$ \\
& $(0.010)$ & $(0.008)$ & $(0.011)$ & $(0.025)$ & $(0.020)$ & $(0.027)$ \\
Pakistan/Turkey 1986-90 & $-0.438^{* * *}$ & $-0.310^{* * *}$ & $-0.265^{* * *}$ & $-0.207^{* * *}$ & $-0.142^{* * *}$ & $-0.331^{* * *}$ \\
& $(0.014)$ & $(0.012)$ & $(0.023)$ & $(0.027)$ & $(0.019)$ & $(0.039)$ \\
Refugees 1986-90 & $-0.433^{* * *}$ & $-0.253^{* * *}$ & $-0.268^{* * *}$ & $-0.266^{* * *}$ & $-0.038^{* * *}$ & $-0.106^{* * *}$ \\
& $(0.007)$ & $(0.006)$ & $(0.009)$ & $(0.010)$ & $(0.008)$ & $(0.015)$ \\
Balkans 1991-95 & $-0.404^{* *}$ & $-0.291^{* * *}$ & N/A & $-0.223^{* *}$ & $-0.052^{* * *}$ & N/A \\
& $(0.009)$ & $(0.009)$ & & $(0.009)$ & $(0.009)$ & \\
Refugees 1996-2000 & $-0.366^{* * *}$ & $-0.428^{* * *}$ & N/A & $-0.233^{* * *}$ & $-0.242^{* * *}$ & N/A \\
& $(0.010)$ & $(0.012)$ & & $(0.019)$ & $(0.019)$ & \\
New EU 2004-07 & $-0.258^{* * *}$ & N/A & N/A & $-0.264^{* * *}$ & N/A & N/A \\
& $(0.007)$ & & & $(0.010)$ & & \\
\hline & & & & & & \\
\end{tabular}

*/**/*** Significant at the 10/5/1 percent level.

Note: Standard errors, clustered within individuals, are reported in parentheses. In addition to control variables listed in note to Table 2, regression also includes log municipality unemployment rate interacted with indicators for natives and each immigrant cohort (for a total of 320 regressors). The regression samples consist of $3,278,771$ observations of 169,767 men and $2,367,442$ observations of 138,814 women. 
For the early labor migrants from Pakistan and Turkey, earnings gradually lag behind those of natives, and the estimated earnings differential (among those employed) after 25 years is close to 30 percent (see Table 3). For family immigrants from Pakistan and Turkey, the earnings differentials after 25 years are large and similar to those of their labor migrant predecessors.

Among the refugee cohorts the evidence shows clear patterns of earnings assimilation. As for employment, after a 10-year period with substantial assimilation, earnings of refugee women from the 1980s and from the Balkans are very similar to those of native women. And again, refugees from the late 1990s experience significantly larger differences relative to natives than the other two groups of humanitarian immigrants.

Immigrants tend to receive a disproportional share of temporary social insurance transfers such as unemployment benefits, in part because of the sensitivity of their labor market performance to negative macroeconomic shocks. From a fiscal as well as an overall efficiency perspective, permanent withdrawal from the labor market including entry into long-term disability programs is, however, of greater concern. In Figure 8 we display the predicted difference in disability program participation between immigrants and natives, based on linear probability model estimation of equations (1) and (2) with disability program participation in any given calendar year as the outcome measure. Table 4 reports predicted differences and standard errors at selected years after arrival.

While Western European labor migrants from the 1970s had disability rates that were very similar to those of natives of the same age, education, and family structure, disability program participation among Pakistani and Turkish immigrants differed dramatically. After 25 years in Norway (or age 50), the male differential is close to 30 percentage points (and about three times the participation among natives). As discussed in Bratsberg et al. (2010), the sharp drop in employment among non-European labor migrants was to some extent triggered by cyclical downturns in the early 1980s and early 1990s and by structural change in Norwegian industry, which hit certain manufacturing industries where immigrants from low-income countries were somewhat overrepresented particularly hard. But these developments cannot explain why so many of the immigrants failed to return to the labor market, e.g., by reorienting themselves towards other industries. One contributing factor to explaining the failure to return to the labor market was that many of the migrants from low-income source countries had earnings and family structures yielding relatively high replacement ratios in the social insurance system, thus undermining the financial incentives for re-entry into the labor market.

The recent Eastern European labor migrants have very low rates of disability program participation. Labor migrants are presumably positive selected on health as they had jobs at the time of arrival and the process of entering disability programs is often extensive, involving long-term sickness and/or long-term unemployment. From this perspective, we are unable to predict lifecycle disability program participation after observing the immigrant cohort for only a short period in Norway.

As Figure 8 shows, disability program participation among Pakistani and Turkish family immigrants grows substantial over time with participation rates after 25 years 13 to 16 percentage points higher than among natives (see Table 4). Taken together, the employment and disability patterns displayed in Figures 6 and 8 do not convey a story of labor market assimilation for the chain migrants that joined the original labor migrant cohort from developing countries. Instead, for these groups immigrant-native differentials in employment and disability program participation are exacerbated with years since arrival. 


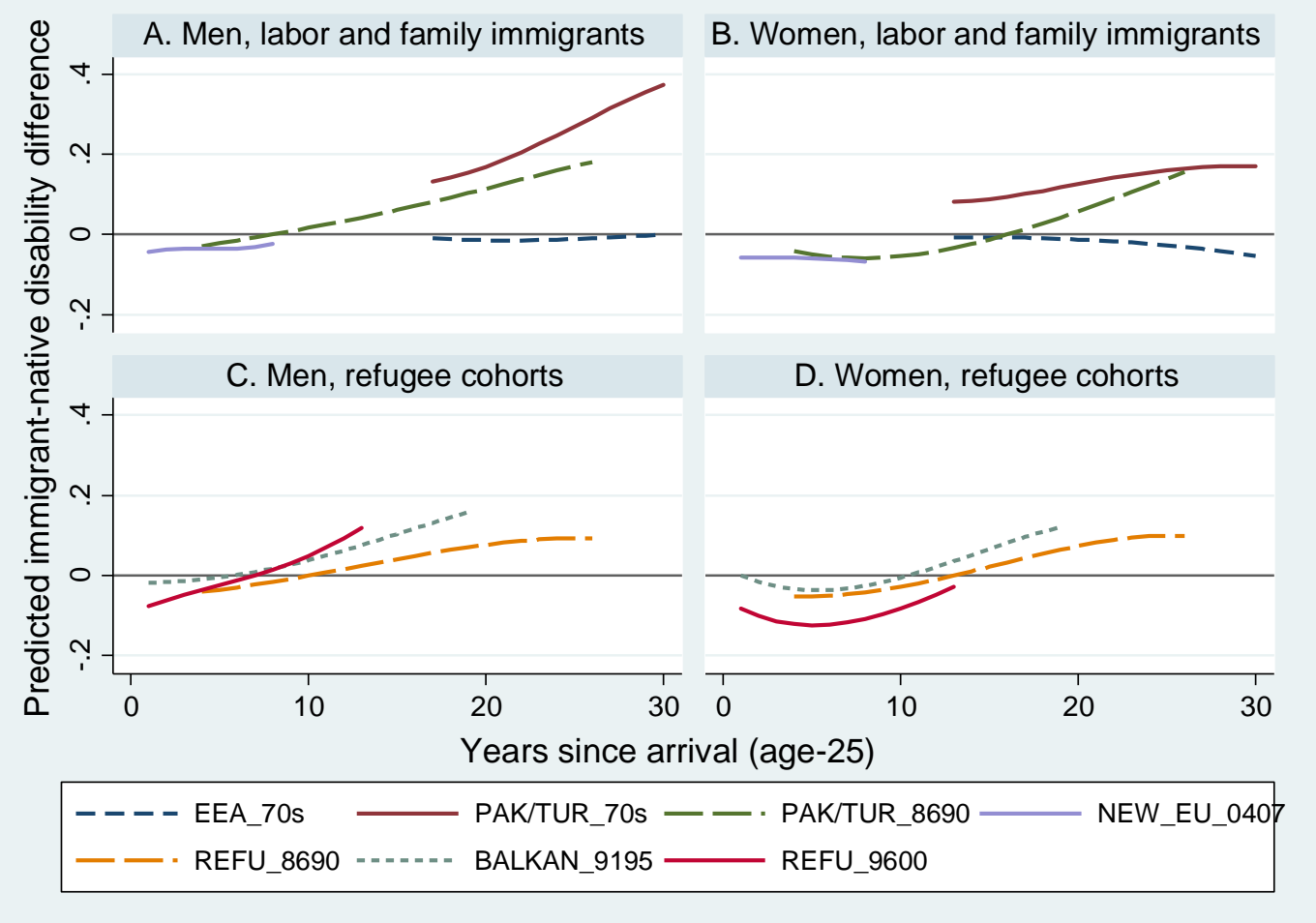

Figure 8: Disability program participation rate. Predicted difference between immigrants and natives.

Table 4: Predicted immigrant-native disability program participation differentials

\begin{tabular}{lccc|ccc}
\hline & & Men & & \multicolumn{3}{c}{ Women } \\
Years since arrival: & 5 & 15 & 25 & 5 & 15 & 25 \\
\hline Immigrant cohort: & & & & & & \\
EEA 1970s & N/A & -0.001 & $-0.011^{*}$ & N/A & -0.006 & $-0.028^{* * *}$ \\
& & $(0.016)$ & $(0.006)$ & & $(0.006)$ & $(0.006)$ \\
Pakistan/Turkey 1970s & N/A & $0.118^{* * *}$ & $0.270^{* * *}$ & N/A & $0.087^{* * *}$ & $0.160^{* * *}$ \\
& & $(0.028)$ & $(0.010)$ & & $(0.019)$ & $(0.015)$ \\
Pakistan/Turkey 1986-90 & $-0.022^{* * *}$ & $0.061^{* * *}$ & $0.170^{* * *}$ & $-0.049^{* * *}$ & -0.012 & $0.139^{* * *}$ \\
& $(0.006)$ & $(0.009)$ & $(0.017)$ & $(0.006)$ & $(0.010)$ & $(0.021)$ \\
Refugees 1986-90 & $-0.035^{* * *}$ & $0.041^{* * *}$ & $0.093^{* * *}$ & $-0.052^{* * *}$ & $0.022^{* * *}$ & $0.099^{* * *}$ \\
& $(0.003)$ & $(0.004)$ & $(0.008)$ & $(0.003)$ & $(0.006)$ & $(0.013)$ \\
Balkans 1991-95 & -0.005 & $0.104^{* * *}$ & N/A & $-0.037^{* * *}$ & $0.066^{* * *}$ & N/A \\
& $(0.005)$ & $(0.008)$ & & $(0.005)$ & $(0.009)$ & \\
Refugees 1996-2000 & $-0.025^{* * *}$ & $0.093^{* * *}$ & N/A & $-0.124 * * *$ & $-0.048^{* * *}$ & N/A \\
& $(0.005)$ & $(0.009)$ & & $(0.006)$ & $(0.011)$ & \\
New EU 2004-07 & $-0.036^{* * *}$ & N/A & N/A & $-0.059^{* * *}$ & N/A & N/A \\
& $(0.003)$ & & & $(0.004)$ & & \\
\hline
\end{tabular}

$* / * * / * * *$ Significant at the 10/5/1 percent level.

Note: Standard errors, clustered within individuals, are reported in parentheses. Regression includes control variables listed in note to Table 2 . The regression samples consist of 2,559,167 observations of 171,442 men and $2,294,845$ observations of 145,573 women. 
For the refugee cohorts, very few were enrolled in disability programs during the first years after arrival, partly reflecting that entitlement takes time. After about ten years, however, the immigrantnative participation differentials turn positive and the estimates in Table 4 display significant and substantial differences 15 years after arrival. Male refugees from the late 1990s experienced declining employment after about 5 years and Figure 8 shows that this is accompanied by an increase in disability program participation. Generally speaking, across groups and years since arrival we find that low employment rates go along with high disability program participation rates.

Although the evidence presented in Figures 6-8 indicate that there exist structural forces in the Norwegian labor market and welfare system that create barriers for long employment careers for immigrants from low-income countries, they also demonstrate substantial heterogeneity in labor market performance across origin countries. In particular, we find large differences in labor market assimilation across cohorts of humanitarian immigrants. While those admitted on humanitarian grounds from the wars in Somalia and Iraq during the 1990s do poorly in the labor market even a decade after arrival, refugees from the Balkan wars and the diverse group of refugees from the 1980s, arriving from Vietnam, Chile, Sri Lanka, and Iran, tend to perform quite well in Norwegian labor market. Female refugees, in particular, experience substantial assimilation with employment and earnings almost on par with native women after ten years in the country.

\subsection{Selection and robustness}

Our analyses are based on the subsample of immigrants who stayed in Norway for at least five years. But, as Table 1 showed, for several of the immigrant groups under study a large fraction of the original cohort had left the country within five years of arrival. This brings up the question of whether the analyzed samples are representative of immigrants in general. Theories of migrant selection, such as Tunali (1986) and Borjas and Bratsberg (1996), predict that outmigrants will not be randomly selected from the pool of immigrants. For example, if returns to skill in the source country exceed those in the host country, outmigrants may be positively selected from the pool of immigrants and, on average, possess higher skills than those who stay for the long term. On the other hand, unexpected weak labor market outcomes during the initial period in the host country are expected to influence return migration decisions. In other words, outmigration may be associated with both favorable and weak labor market outcomes.

To address the issue of selective outmigration, Appendix Table A-1, columns IV-VII, reports employment rates and log earnings during the first two years upon arrival among immigrants who left the country in years three and four with the outcomes of immigrants who stayed for at least five years. The table reveals significant differences between outmigrants and stayers for a majority of the immigrant groups considered. For some groups, and notably the 1970 s cohort of labor migrants from Western Europe, those who left had higher employment rates and higher earnings than those who settled in Norway. Conversely, for other groups, such as the recent cohort of labor migrants from Eastern Europe, the comparison shows that stayers had significantly better outcomes than outmigrants. The evidence therefore points to both positive and negative selection in outmigration behavior and it is not clear that our focus on those who stay for at least five years yields an unbalanced picture of the labor market and social insurance outcomes of immigrants in general.

The appendix table also shows cumulative outmigration rates 5, 10, and 15 years after arrival (see columns I-III). These numbers reveal that the majority of outmigration events take place soon upon 
entry. Even so, a fair number of immigrants leave the country between 5 and 15 years after arrival (the weighted mean outmigration rates across the various cohorts at 5 and 15 years are 23.4 and 30.5 percent). This raises the concern that our assessments of relative employment progress with time in Norway may be biased if any selection in outmigration flows is correlated with years since migration. Similarly, the analyses above showed that, conditional on staying in Norway, employment rates between years 5 and 15 fell for some groups (notably the early labor migrants from Pakistan and Turkey) as immigrants left the labor market and enrolled in disability programs, and increased for other groups (notably women). Such variation in labor market participation with years in the country raises another concern, that our assessment of relative earnings progress of immigrants may be biased if labor market participation is correlated with unobserved individual factors.

In Appendix Table A-2, we investigate whether our estimates of relative immigrant employment and earnings progress are impaired by selection bias. The table contrasts estimates of the change in immigrant outcomes relative to natives between years 5 and 15 derived from the analysis above (columns headed "full sample") with estimates based on a panel of individuals where inclusion in the employment equation is based on presence in Norway, and that in the earnings equation, on employment, both 5 and 15 years after arrival. While the full-sample estimates are subject to selection bias from compositional change, the panel-based estimates are not. The table reveals that, low and behold, the two sets of estimates are quite similar. For example, for the early cohort of labor migrants from Pakistan and Turkey, where a large fraction left employment between years 5 and 15, estimates of relative earnings change are the same whether based on the full sample or the panel. Such evidence suggests that any selection out of the labor force is not strongly correlated with years since migration. But, the table also gives some indications of selective behavior. For example, panelbased estimates of employment and earnings progress among Western European labor migrants exceed those based on the full sample, consistent with the observation above that outmigrants from this arrival cohort tend to be positively selected. Likewise, for some of the female groups, where the employment rate increased with time in Norway, panel-based estimates of earnings progress are more positive than those from the full sample-suggesting that labor market participation among female immigrants is positively correlated with unobserved factors in the earnings equation. Nevertheless, these indications of selection bias are of modest size relative to the large differences in long-term economic outcomes uncovered in this paper.

\section{Labor migrant sensitivity to the financial crisis}

Labor market outcomes are more pro-cyclical among immigrants than native workers (Barth et al., 2004; Dustmann et al., 2010). Negative labor demand shocks such as that during the financial crisis are expected to drive up the unemployment rate and unemployment insurance claims among labor migrants in the short run. From a long-term perspective, though, any persistence of non-employment among labor migrants who remain in the host country is of greater concern, as long-lasting unemployment often results in entry into disability programs and permanent labor market exit. The mobility as well as transferability of skills and the ability to acquire new competencies will contribute to successful return to work among those exposed to unemployment shocks. Over the last decade, the European labor market has become more integrated with favorable job opportunities in one country attracting worker inflows from elsewhere in the region. At the same time, social insurance programs differ greatly across countries and receiving countries may fear the emergence of persistent unemployment among labor migrants following reductions in labor demand. 
With the large inflows of workers from Eastern Europe following the 2004 EU extension, the Norwegian experience during the financial crisis presents a particularly interesting case as we are able to track careers of individual labor migrants and study the interplay between the labor market and the unemployment insurance program. In this section we therefore focus on the employment dynamics of the 2004-2007 arrival cohort from Eastern Europe. As in the prior section, we study migrants who remained in Norway for at least five years. We augment the study of long-term social insurance outcomes of the prior section and focus on unemployment insurance claims instead of disability insurance. With a benefit replacement ratio of 62.4 percent and huge differences in wages between Norway and home countries in Eastern Europe, Norwegian unemployment benefits will typically pay much more than what can be earned from fulltime employment at home. ${ }^{6}$

Figure 9 shows that unemployment among the labor migrants rose quickly after the onset of the financial crisis. Between October 2008 and March 2009, the share of male labor migrants receiving unemployment benefits increased from 1.4 to 11.3 percent. Male unemployment peaked during the winter months of 2010, with unemployment rates of 15.5 percent among labor migrants compared to 3.5 percent among natives. When we consider the cumulative incidence of unemployment over the entire 2009-2010 period, 36.8 percent of the male migrants were registered as benefit claimants compared to 9.9 percent of native men (see Table 5, column I). The unemployment shock was less severe for women, but again with a huge differential and cumulative unemployment incidence among immigrant women almost three times that of native women. Even if immigrant unemployment dropped significantly during the recovery period in 2011-2012, the figure reveals that it never quite returned to its pre-crisis level and remained persistently above the rates for natives. Although the rise in unemployment was less dramatic for immigrant women, their unemployment rate remained at a high level after the crisis and by 2013 unemployment among female migrants was actually significantly higher than that for men.

Unemployment risk differs considerably across workers and the higher exposure of labor migrants may reflect the type of industry and occupation they came to, as well as their shorter job tenure at the time of the cyclical downturn. To examine these explanations, we perform a set of regression analyses where we explain employment and unemployment outcomes as functions of industry, occupation, and job tenure. For this purpose, we focus on those who were employed in 2008 and for whom we can identify industry, occupation, and tenure (measured in the last job prior to the onset of the financial crisis). The regression analysis includes the extract of native comparison persons from the prior section but subject the same sample criteria as in the immigrant samples (i.e., wage earner in 2008 and in the relevant age range).

Columns I and IV in Table 5 reveal that the immigrant-native unemployment differential falls substantially when we account for differences in tenure, age, occupation and industry. In fact, differences in such job characteristics explain 40 percent of the observed male unemployment incidence differential and 60 percent of that among women.

\footnotetext{
${ }^{6}$ Bratsberg et al. (2014) show that the outmigration rate in the broader group of Eastern European labor migrants was quite modest during the financial crisis, and point to the more adverse impacts of the crisis on labor markets at home as a contributing factor.
} 


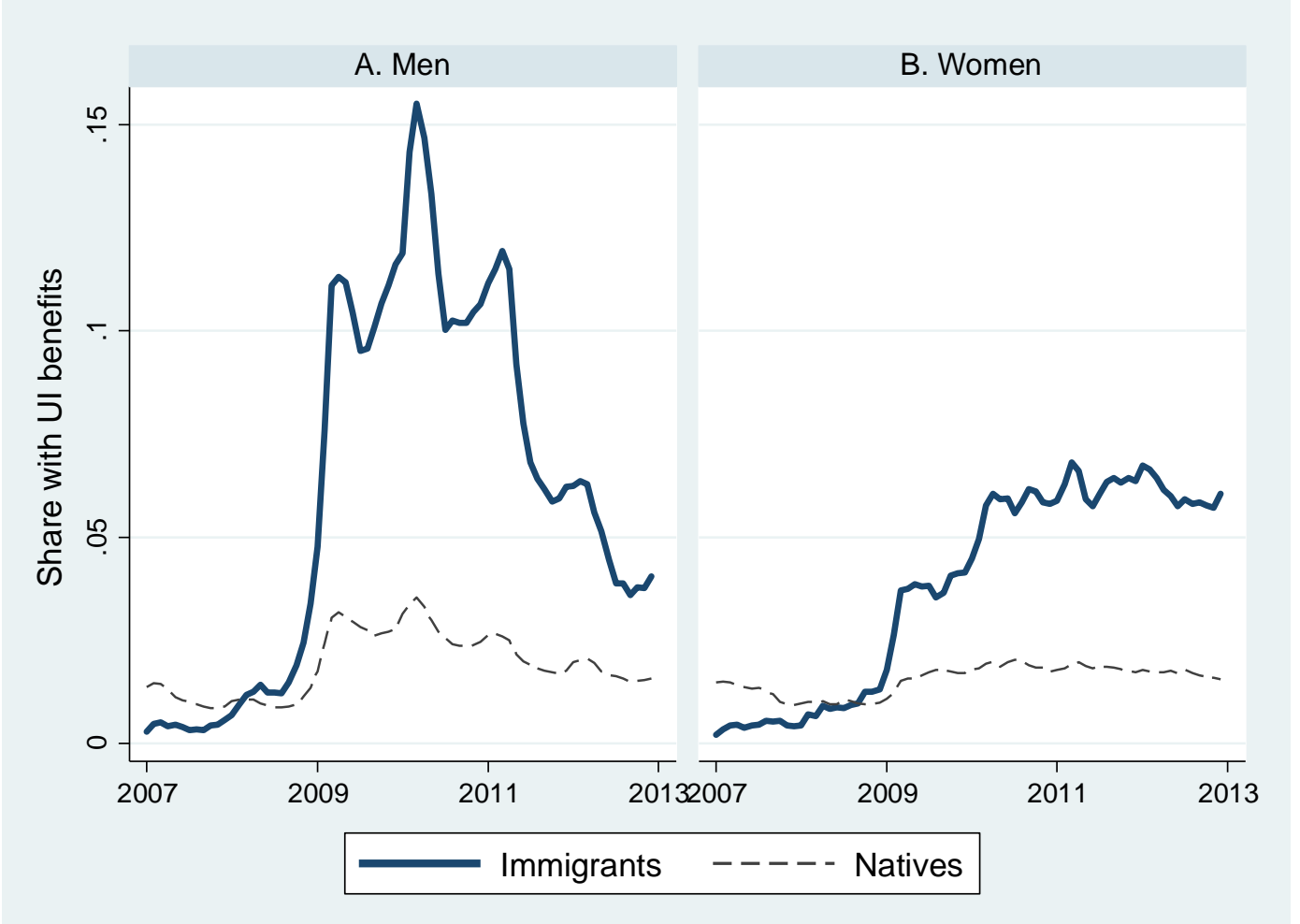

Figure 9: Unemployment insurance receipts at end of the month, January 2007-December 2012. Labor migrants from Eastern Europe and native reference groups.

Note: Immigrant sample consist of 2004-2007 migrants from Poland and Lithuania; age 17-36 at arrival; employed in 2008; and present in Norway 1.1.2013. Native samples are based on the 10 percent extracts used in section 3 and are stratified to match the age distribution of the immigrant samples. Samples consist of 7,519 immigrant and 34,493 native men and 2,353 immigrant and 33,007 native women.

Turning to the post-crisis employment rates in 2012, we observe lower employment rates among immigrants compared to natives of the same gender, with employment among immigrant men 6.5 percentage points and that of immigrant women 5.8 percentage points below natives. When we compare workers in similar jobs, however, as in the adjusted differences reported in columns II and $V$, the employment differential actually disappears for women and falls to just 1.6 percentage points for men.

Finally, in columns III and VI we consider the persistence of non-employment by estimating 2012 employment differentials for those with an unemployment spell during the crisis years of 2009-2010. These columns show that immigrants are less likely than natives to (re)enter employment in 2012, but that the difference is not large and that it fully disappears when we compare those who were in similar jobs prior to the crisis. It follows that labor migrants' employment careers in Norway are particularly vulnerable to economic downturns for the simple reason that immigrants tend to fill unstable jobs. 
Table 5: Employment in 2012 and unemployment insurance in 2009/2010, recent labor immigrants from Eastern Europe

\begin{tabular}{|c|c|c|c|c|c|c|}
\hline & \multicolumn{3}{|c|}{ Men } & \multicolumn{3}{|c|}{ Women } \\
\hline & $\begin{array}{c}\text { I } \\
\text { Unemploy- } \\
\text { ment } \\
\text { insurance } \\
2009 / 2010\end{array}$ & $\begin{array}{c}\text { Employed } \\
2012 \\
\end{array}$ & $\begin{array}{c}\text { III } \\
\text { Employed } \\
2012 \text { if } \\
\text { unempl'd } \\
2009 / 2010\end{array}$ & $\begin{array}{c}\text { IV } \\
\text { Unemploy- } \\
\text { ment } \\
\text { insurance } \\
2009 / 2010 \\
\end{array}$ & $\begin{array}{c}\text { Employed } \\
2012 \\
\end{array}$ & $\begin{array}{c}\text { VI } \\
\text { Employed } \\
2012 \text { if } \\
\text { unempl'd } \\
2009 / 2010 \\
\end{array}$ \\
\hline Immigrant average & 0.368 & 0.886 & 0.857 & 0.208 & 0.872 & 0.810 \\
\hline Native average & 0.099 & 0.951 & 0.872 & 0.075 & 0.930 & 0.869 \\
\hline Imm-native difference & 0.269 & -0.065 & -0.015 & 0.133 & -0.058 & -0.059 \\
\hline $\begin{array}{l}\text { Difference controlled } \\
\text { for age, tenure, } \\
\text { industry, occupation }\end{array}$ & $\begin{array}{c}0.169 * * * \\
(0.007)\end{array}$ & $\begin{array}{c}-0.016 * * * \\
(0.005)\end{array}$ & $\begin{array}{c}0.011 \\
(0.013)\end{array}$ & $\begin{array}{c}0.057^{* * *} \\
(0.010)\end{array}$ & $\begin{array}{c}0.008 \\
(0.009)\end{array}$ & $\begin{array}{l}-0.007 \\
(0.024)\end{array}$ \\
\hline
\end{tabular}

Note: Standard errors are reported in parentheses. Samples are restricted to wage earners in 2008 (i.e., those with registered tenure, industry, and occupation) who remained present in Norway in 2012. Control variables include a quartic polynomial of age, tenure and its square, and indicators for 2-digit industry and occupation in 2008 (for a total of 114 regressors). Dependent variable in cols I and IV is an indicator for receipt of unemployment insurance in 2009 or 2010 . Observation counts are as follows: 7,519 immigrants and 34,493 natives (cols I-II); 2,764 immigrants and 3,414 natives (col III); 2,353 immigrants and 33,007 natives (cols IV and V); and 490 immigrants and 2,485 natives (col VI). See also note to Figure 9.

In sum, recent labor migrants from Eastern Europe were far more exposed to job loss during the financial crisis than comparable native workers. And, immigrant unemployment shows greater persistence as immigrant workers have a lower probability of returning to employment once an unemployment spell has occurred. The post-crisis level of employment among labor migrants is lower than that for natives, but the difference is minor relative to the substantial short-run variation in unemployment incidence observed during the economic downturn and largely explained by differences in tenure, industry and occupation at the onset of the financial crisis.

\section{Children of 1970s non-European labor migrants}

In the longer term, the fiscal impacts of immigration will hinge on the human capital accumulation and labor market outcomes of their descendants. Fertility differences between immigrants and natives also form a key factor in the dynamic analysis of fiscal consequences of immigration, as higher fertility in the immigrant population will alter the composition of age groups with negative and positive fiscal balances (Preston2013). The rate of immigrant-native convergence in fertility is of interest in its own right as it signals the degree of immigrant integration and assimilation in general. In this section, we examine education, family, labor market, and social insurance outcomes of the children of the early labor migrants from Pakistan and Turkey. Given the poor lifecycle labor market performance of their parents, the question of how their offspring perform in the labor market and form families is of considerable interest. Will their employment and fertility careers resemble those of their parents, or can we expect them to converge quickly to the outcomes of natives? 
Prior research shows that age at immigration is important for economic and social outcomes, and that immigrant children who arrived before school age have better educational outcomes than their older siblings (Böhlmark, 2008; Bratsberg et al., 2012). For this reason, we distinguish between immigrant offspring born in Norway and children who came to Norway with their parents (typically with their mother, 5-10 years after the father's original entry), and split child immigrants according to arrival before and after school age (0-6 vs 7-16). Throughout this section, we compare the offspring of the immigrants from Pakistan and Turkey with a reference group born to native parents and with the same distribution of birth year as the second generation immigrants. With data including 2012, we can follow these second generation immigrants into their mid-thirties. This offers ample opportunity for examining final educational attainment, whereas labor market and social insurance outcomes and fertility patterns can be traced only in the beginning of their career. As for their parents, both unadjusted and conditional differentials relative to native born are of interest. Evidence of intergenerational assimilation is provided by comparing the outcomes for offspring born in Norway and the outcomes of their parents described in section 3.

To begin, in Table 6 we report observed outcomes at age 30 for the various groups of offspring. We consider three levels of educational attainment: Completion of upper secondary education, college/university, and a postgraduate degree by age 30. It is evident from the table that, on average, the children of the labor migrant cohort obtained less education than the native comparison group both in terms of completed secondary school and college. However, exposure to the host country school environment seems to matter as immigrant children born in Norway have much better educational outcomes than those born abroad and those who arrived before school age have better outcomes than their older siblings.

Indeed, a striking feature of the table is that, among offspring born in Norway, a somewhat larger fraction has completed a postgraduate degree by age 30 compared to natives (10.1 vs. 9.9 percent for sons and 10.9 vs. 10.3 for daughters). Moreover, a closer look at the underlying data (not reported in Table 6) reveals that, among those with a postgraduate degree, immigrant children are overrepresented in high-earnings fields of study such as medicine. In fact, within the post-graduate bracket, fully 41 percent of immigrant sons and 49 percent of daughters born in Norway had completed medical school by age 30, compared to 7 and 10 percent of sons and daughters with a post-graduate education in the native comparison group. At the same time, the fraction of immigrant children who did not complete upper secondary education exceeds that in the native comparison group. Immigrant children outdo native children in both ends of the educational distribution, leading to much greater variability in outcomes among second generation immigrants than children of natives.

Compared to their parents, the immigrant offspring born in Norway have completed far more years of schooling. While only 33 percent of the fathers had completed upper secondary school (see Table 1), the completion rate among sons is 57 percent. The intergenerational improvement is even more striking among women: only 18 percent of the 1970s female immigrants from Pakistan and Turkey had completed upper secondary school, compared to 66 percent of daughters born in Norway. The attainment gap relative to natives is significantly reduced and the gender difference is turned around from one generation to the next, with girls becoming more successful in school (as is the case for native children). 
Table 6: Educational attainment and family and labor market outcomes at age 30, children of labor immigrants from Pakistan and Turkey

\begin{tabular}{|c|c|c|c|c|c|c|c|c|}
\hline & \multicolumn{4}{|c|}{ Sons } & \multicolumn{4}{|c|}{ Daughters } \\
\hline & $\begin{array}{l}1 \\
2^{\text {nd }} \text { gen } \\
\text { born } \\
\text { abroad } \\
\text { (7-16 at } \\
\text { arrival) }\end{array}$ & $\begin{array}{l}\text { II } \\
2^{\text {nd }} \text { gen } \\
\text { born } \\
\text { abroad } \\
\text { (0-6 at } \\
\text { arrival) }\end{array}$ & $\begin{array}{c}\text { III } \\
2^{\text {nd }} \text { gen } \\
\text { born in } \\
\text { Norway }\end{array}$ & $\begin{array}{c}\text { Native } \\
\text { ref }\end{array}$ & $\begin{array}{c}\mathrm{V} \\
2^{\text {nd }} \text { gen } \\
\text { born } \\
\text { abroad } \\
\text { (7-16 at } \\
\text { arrival) }\end{array}$ & $\begin{array}{c}\mathrm{Vl} \\
2^{\text {nd }} \text { gen } \\
\text { born } \\
\text { abroad } \\
\text { (0-6 at } \\
\text { arrival) }\end{array}$ & $\begin{array}{c}\text { VII } \\
2^{\text {nd }} \text { gen } \\
\text { born in } \\
\text { Norway }\end{array}$ & $\begin{array}{c}\text { Native } \\
\text { ref }\end{array}$ \\
\hline $\begin{array}{l}\text { Completed upper } \\
\text { secondary }\end{array}$ & 28.6 & 47.0 & 56.6 & 74.6 & 34.4 & 53.0 & 65.5 & 80.2 \\
\hline Completed college & 8.4 & 20.7 & 25.9 & 32.8 & 10.9 & 20.8 & 32.6 & 49.3 \\
\hline Postgrad degree & 2.7 & 6.5 & 10.1 & 9.9 & 2.3 & 5.6 & 10.9 & 10.3 \\
\hline $\begin{array}{l}\text { Married, spouse } \\
\text { present }\end{array}$ & 76.8 & 69.8 & 53.7 & 21.3 & 83.9 & 77.2 & 64.1 & 31.1 \\
\hline Spouse immigrant & 93.6 & 88.0 & 76.7 & 6.6 & 95.7 & 91.1 & 78.2 & 5.1 \\
\hline $\begin{array}{l}\text { Spouse native-born } \\
\text { to immigrant parents }\end{array}$ & 2.4 & 8.7 & 16.5 & 0.1 & 0.9 & 4.0 & 11.3 & 0.2 \\
\hline Children & 1.8 & 1.3 & 0.9 & 0.7 & 2.0 & 1.7 & 1.3 & 1.1 \\
\hline \multicolumn{9}{|c|}{ Outcomes if not enrolled in school: } \\
\hline Employment rate & 0.769 & 0.832 & 0.820 & 0.908 & 0.535 & 0.568 & 0.658 & 0.867 \\
\hline $\begin{array}{l}\text { Disability program } \\
\text { participation rate }\end{array}$ & 0.111 & 0.085 & 0.093 & 0.065 & 0.157 & 0.169 & 0.131 & 0.079 \\
\hline Observations & 935 & 600 & 1,291 & 25,742 & 604 & 538 & 1,221 & 22,335 \\
\hline Obs if not in school & 867 & 509 & 1,044 & 20,753 & 556 & 456 & 991 & 17,035 \\
\hline
\end{tabular}

Note: Employment and disability data are for those not enrolled in school at age 29 or 30 . The native reference group is stratified to match the distribution of birth year of second generation immigrants.

Family structures differ importantly across groups. The marriage rate is particularly high for immigrant children who arrived after school starting age, with 77 percent of sons and 84 percent of daughters married at age 30. Even the immigrant offspring born in Norway are much more likely to be married at 30 than natives. Further, an overwhelming majority of second generation immigrants find their spouse abroad or in the immigrant community. Depending on the group considered, between 90 and 97 percent of the spouses of second generation immigrants are themselves an immigrant or a second generation immigrant. In fact, marriage between a second generation immigrant and someone with Norwegian-born parents is very rare. Across groups, variation in fertility mirrors that in marital status as the number of children is increasing in age at immigration and even for second generation immigrants born in Norway, slightly higher than for young native adults.

From an intergenerational perspective, fertility patterns are of particular interest as the second generation immigrants considered in this section grew up with many more siblings than the native children in the reference group (see Figure 10). The relatively high fertility rates of their parents also 
likely played an important role in explaining the low lifecycle labor force participation patterns of the 1970s cohort of labor migrants and their spouses (Bratsberg et al., 2010). Given that relatively few members of the offspring generation at the present stage can be observed above age 35 , it is too early to draw firm conclusions regarding completed fertility. It is possible, though, to examine fertility-by-age profiles for the offspring up to around age 35 as shown in Figure 10, and contrast these both within and across generations. For women, Figure 10 reveals substantial convergence to native fertility patterns from one generation to the next. Age at immigration seems to matter and immigrant daughters born in Norway have very similar fertility rates as young native women. At age 35 , the female immigrants who arrived during the 1970s had on average given birth to 3.4 children, roughly twice that of native women. Their daughters born in Norway, in contrast, had only 1.9 children compared to about 1.7 among daughters of native parents.

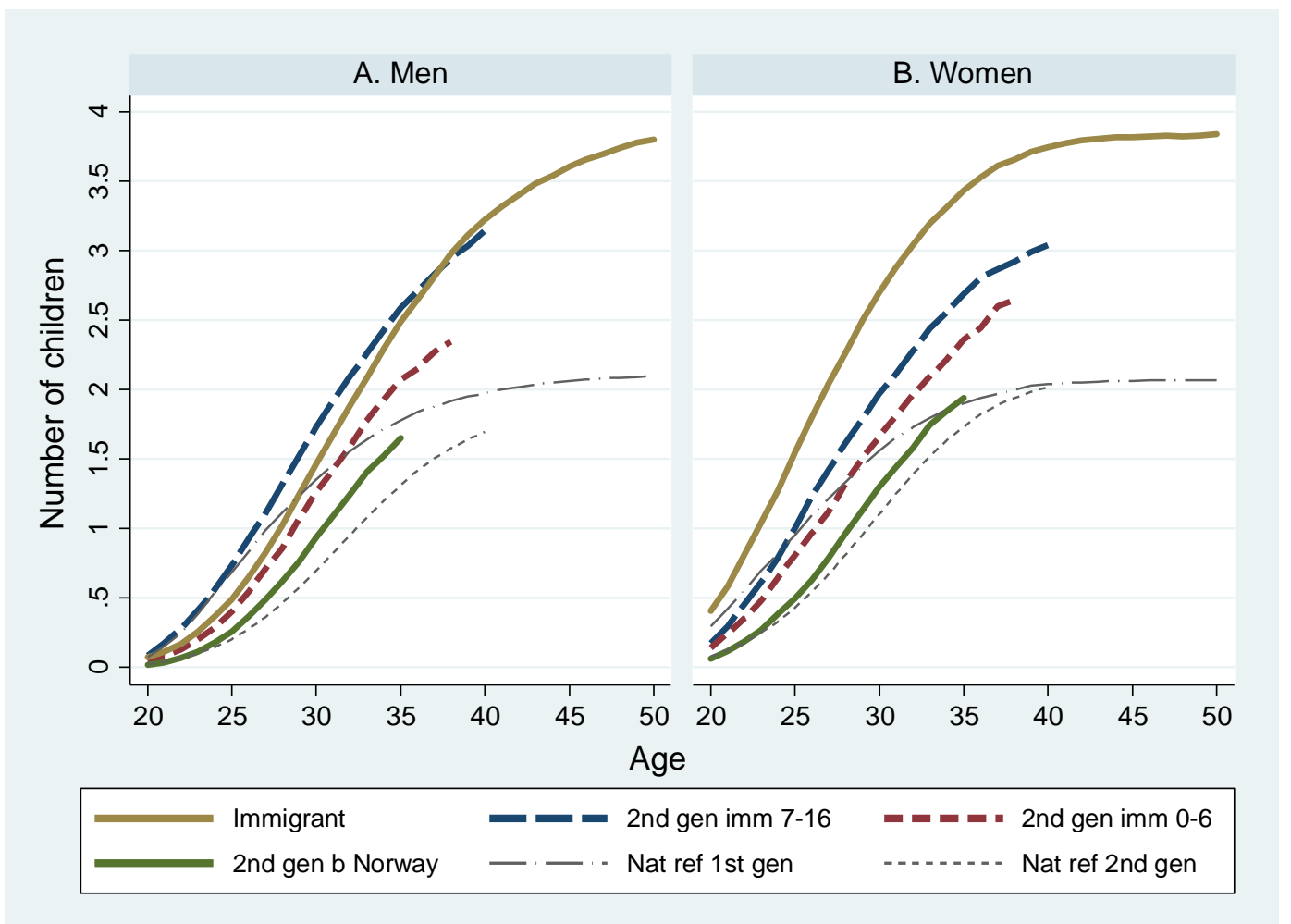

Figure 10: Number of children ever born by age, 1970s immigrant cohorts from Pakistan and Turkey and their children compared to natives.

The convergence to native fertility is also present among men, though less evident than among women. Again, age at immigration appears important and second generation sons born in Norway have much lower fertility than those born abroad. At age 35, male second generation immigrants who arrived after school starting age have, on average, 2.6 children, and those born in Norway 1.6 children, compared to 1.3 among native men of the same generation.

Returning to the labor market outcomes in Table 6, we see that employment rates at age 30 of second generation immigrants are substantially lower than those of natives. For immigrant 
daughters, the gap is particularly large and increasing in age at immigration. While 87 percent of 30 year old native women not in education are employed, the percentage is only 54 among immigrant daughters who arrived after school starting age. Employment profiles are displayed in Figure 11, panels $A$ and $B$, where we simply show the unadjusted employment differential relative to natives by age (i.e., not accounting for differences in education and family structure, but accounting for observation year and fitting a quartic polynomial of age to the data). For second generation immigrant men, the employment differential is around 10-15 percentage points during the age interval 25-35. Among women, the employment differential is increasing in age and approaches 40 percentage points at age 35 for immigrant daughters who arrived after school starting age. Earnings differentials among those employed are displayed in panels C and D. Immigrant sons and daughters born in Norway have earnings closest to young natives with an earnings gap of less than 10 percent. And again, immigrant children who arrived after school starting age are the least successful with an earnings gap among daughters exceeding 20 percent.

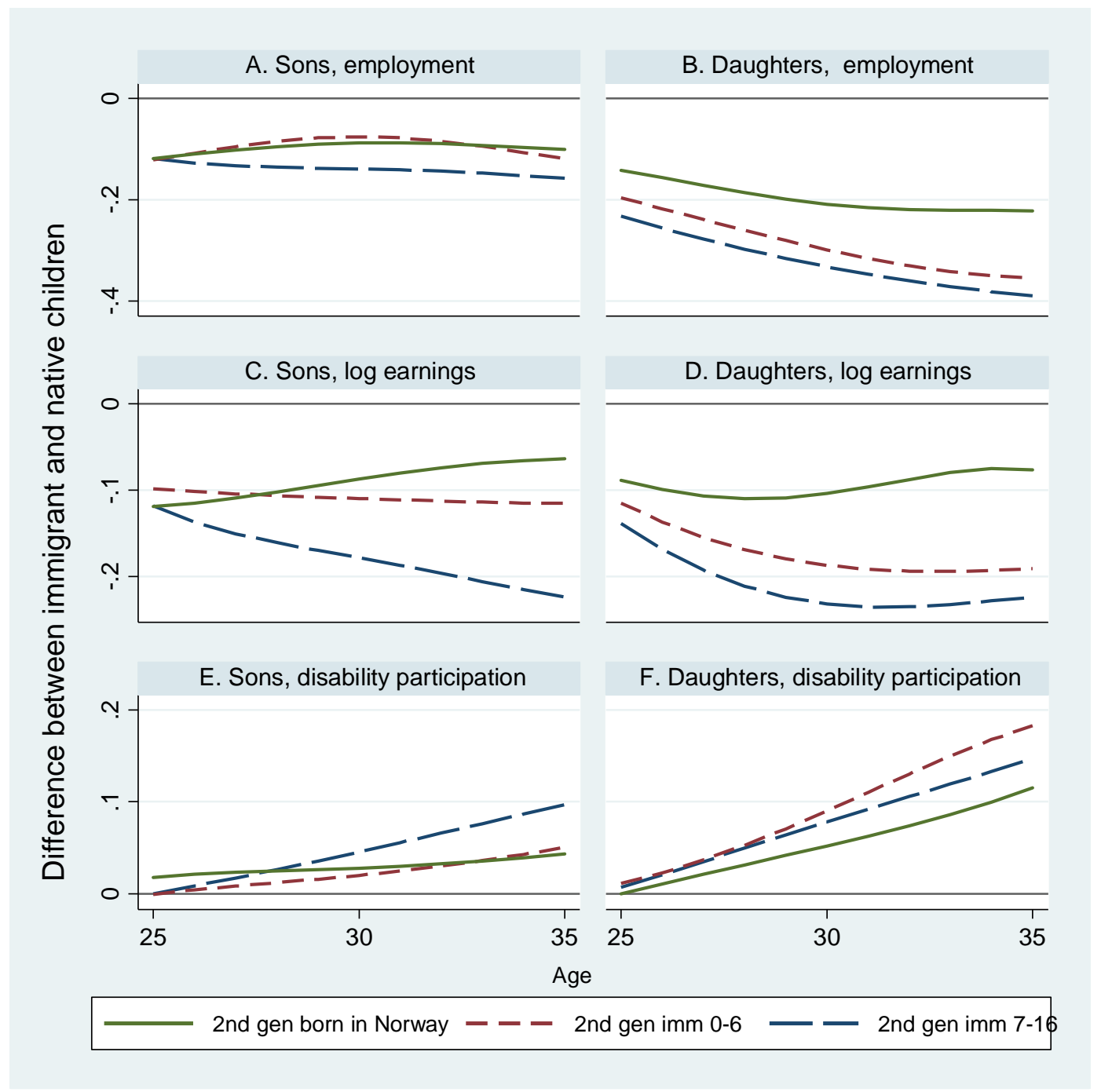

Figure 11: Differences in employment rate, log earnings, and disability program participation rate between children of labor immigrants from Pakistan and Turkey and natives. 
Like their parents, second generation immigrants are overrepresented in disability programs. At age 30 , around 15 percent of immigrant daughters receive disability benefits, about twice the level of natives (see Table 6). For immigrant sons, about 10 percent are enrolled in a in disability program, compared to 6.5 percent of the native reference group. The age profiles in Figure 11 indicate that these differentials can be expected to rise during the years to come. Among immigrant daughters born abroad, the disability differentials relative to natives are growing rapidly with age.

Next we account for differences across groups in educational attainment, family structure and fertility, all of which may explain parts of the observed gaps in labor market outcomes. In Table 7, we adopt a similar empirical strategy as we did in Section 3 for the parent generation and study conditional differences between immigrant and native children in terms of employment, earnings, and participation in disability programs, but evaluated at age 25,30 , and 35 rather than years since arrival. The differentials are based on coefficients from a standard regression framework jointly estimating age profiles for each offspring group, and controlling for educational attainment, marital status, number of children, year of observation, and, in the earnings equation, log municipal unemployment.

Among male second generation immigrants, Table 7, Panel A, reveals small conditional differences in employment of those born abroad and those born in Norway. All three groups have lower employment rates than native children throughout the age interval considered, varying between 5 and 10 percentage points. Immigrant sons born in Norway experienced more rapid earnings growth than their foreign-born siblings, however (see Panel B). In fact, at age 35 their earnings are only marginally below those of the native comparison group. Disability program participation is slightly higher than for young native males with the same educational attainment and family characteristics. In general, when we compare the conditional differentials in Table 7 and the observed (unadjusted) numbers in Figure 11, we see that a substantial part (up to one half at age 35) of the observed differential is accounted for by differences in education and family structure. Comparing immigrant sons who arrived before and after school-starting age, the adjusted differentials in Table 7 imply relative disadvantages at age 30 for those who were 7 to 16 at arrival of five percentage points lower employment and five percent lower earnings. These estimates are in line with those based on Swedish data in Böhlmark (2009).

To provide an intergenerational perspective, we compare outcomes of the two generations after approximately 15 years in the Norwegian labor market. That is, we compare parents 15 years after arrival with offspring born in Norway at age 35. For male employment, the gap relative to natives shows modest improvement and is reduced from 11.5 to 8 percentage points across generations. The intergenerational convergence is much stronger for earnings and disability program participation. From one generation to the next, the male native-immigrant earnings differential declines from 0.253 to 0.040 log points and the immigrant-native difference in disability program participation falls from 11.8 to 2.2 percentage points.

Among daughters, family structure and number of children in particular are strongly correlated with labor market outcomes. The conditional employment differentials among daughters reported in Table 7 are sizable, but close to one half of the observed differences displayed in Figure 11. Employment rates among daughters born abroad are significantly below those of their sisters born in Norway. The unconditional earnings differentials for daughters displayed in Figure 11, Panel D, reveal 
significant variation in earnings by place of birth and age at arrival. But, as Table 7, Panel B, shows, these differentials are almost completely explained by differences in educational attainment and family structure. On the other hand, the more frequent disability program participation observed for female second generation immigrants remains even when we control for education and family structure. The higher disability rates among immigrant daughters compared to natives may reflect intergenerational spillovers and even a causal impact of parental disability insurance (Dahl et al., 2013).

Table 7: Predicted differences in employment, log earnings, and disability program participation between children of labor immigrants from Pakistan and Turkey and natives. Education and family controls.

\begin{tabular}{lccc|ccc}
\hline & \multicolumn{3}{c|}{ Sons } & \multicolumn{3}{c}{ Daughters } \\
Age: & 25 & 30 & 35 & 25 & 30 & 35 \\
\hline A. Employment rate: & & & & & & \\
$2^{\text {nd }}$ generation, born Norway & $-0.081^{* * *}$ & $-0.064^{* * *}$ & $-0.080^{* * *}$ & $-0.092^{* * *}$ & $-0.142^{* * *}$ & $-0.149 * * *$ \\
& $(0.010)$ & $(0.010)$ & $(0.016)$ & $(0.011)$ & $(0.012)$ & $(0.019)$ \\
Born abroad, imm age 0-6 & $-0.083^{* * *}$ & $-0.049^{* * *}$ & $-0.085^{* * *}$ & $-0.133^{* * *}$ & $-0.194^{* * *}$ & $-0.228^{* * *}$ \\
& $(0.015)$ & $(0.013)$ & $(0.017)$ & $(0.017)$ & $(0.018)$ & $(0.023)$ \\
Born abroad, imm age 7-16 & $-0.085^{* * *}$ & $-0.100^{* * *}$ & $-0.099^{* * *}$ & $-0.139^{* * *}$ & $-0.188^{* * *}$ & $-0.212^{* * *}$ \\
& $(0.011)$ & $(0.011)$ & $(0.013)$ & $(0.017)$ & $(0.017)$ & $(0.020)$ \\
B. Log earnings: & & & & & & \\
$2^{\text {nd }}$ generation, born Norway & $-0.088^{* * *}$ & $-0.065^{* * *}$ & $-0.040^{*}$ & $-0.027^{* *}$ & $-0.024^{*}$ & -0.015 \\
& $(0.012)$ & $(0.013)$ & $(0.021)$ & $(0.011)$ & $(0.013)$ & $(0.020)$ \\
Born abroad, imm age 0-6 & $-0.064^{* * *}$ & $-0.070^{* * *}$ & $-0.059^{* * *}$ & $-0.033^{*}$ & $-0.054 * * *$ & $-0.055^{* *}$ \\
& $(0.018)$ & $(0.018)$ & $(0.021)$ & $(0.018)$ & $(0.018)$ & $(0.026)$ \\
Born abroad, imm age 7-16 & $-0.088^{* * *}$ & $-0.116^{* * *}$ & $-0.125^{* * *}$ & -0.020 & $-0.031^{*}$ & -0.012 \\
& $(0.015)$ & $(0.015)$ & $(0.018)$ & $(0.019)$ & $(0.018)$ & $(0.023)$ \\
C. Disability program participation & & & & & & \\
$2^{\text {nd }}$ generation, born Norway & $-0.015^{* *}$ & 0.004 & 0.022 & $-0.034^{* * *}$ & 0.010 & $0.069 * *$ \\
& $(0.007)$ & $(0.008)$ & $(0.014)$ & $(0.008)$ & $(0.010)$ & $(0.018)$ \\
Born abroad, imm age 0-6 & $-0.035^{* * *}$ & -0.009 & 0.017 & $-0.020^{*}$ & $0.033^{* *}$ & $0.112^{* * *}$ \\
& $(0.009)$ & $(0.011)$ & $(0.015)$ & $(0.010)$ & $(0.015)$ & $(0.023)$ \\
Born abroad, imm age 7-16 & $-0.032^{* * *}$ & 0.006 & $0.042^{* * *}$ & $-0.041^{* * *}$ & 0.003 & $0.059^{* * *}$ \\
& $(0.009)$ & $(0.010)$ & $(0.012)$ & $(0.010)$ & $(0.014)$ & $(0.019)$ \\
& & & & & & \\
\hline
\end{tabular}

Note: Standard errors, clustered within individuals, are reported in parentheses. Regression includes quartic polynomial of age; the age polynomial interacted with each immigrant child cohort; and indicators for immigrant child cohort; educational attainment (5 levels); number of children (0, 1, 2, 3, 4 and 5 plus); married, spouse present; previously married; year of observation; and, in panel B, log municipality unemployment rate interacted with native child and each immigrant child cohort (for a total of 69 regressors). The regression samples exclude those enrolled in school the year of or the year prior to the outcome observation. Samples consist of 356,363 observations of 38,390 sons and 270,115 observations of 32,629 daughters in panels $A$ and C, and 312,768 observations of 36,545 sons and 219,988 observations of 30,558 daughters in panel $B$. 
Finally, despite the gaps relative to native children, the differentials found for immigrant daughters in Table 7 indicate substantial assimilation across generations. When we compare outcomes of daughters born in Norway at age 35 with those of their mothers 15 years after arrival, the employment gap relative to natives falls from 30.5 to 14.9 percentage points, the log earnings differential from -0.084 to -0.015 , and the immigrant-native difference in disability program participation declines from 8.7 to 6.9 percentage points.

To summarize our evidence on labor market outcomes and disability program participation among immigrant offspring, we find substantial gaps relative to natives in terms of lower employment and earnings, as well as higher participation in disability programs. Even so, there is clear evidence of assimilation across generations. Immigrant offspring born in Norway are more similar to natives than their parents in terms of educational attainment, labor market outcomes, disability program participation and fertility.

\section{Concluding remarks}

The eastwards enlargement of the common European labor market in 2004 represents in many ways a huge social experiment. It has triggered migration flows within Europe on an unprecedented scale. Even during the 1980s and 1990s, the immigrant share of the population increased substantially in most high-income countries, and over the decades the composition of the immigrant population changed radically with increasing inflows from low-income countries (Bauer et al., 2000; Blau et al., 2011). While scholars tend to emphasize the large economic gains associated with liberalizing international migration, voters and policy makers in Western Europe have become increasingly concerned that the large cross-country differences in living standards, wages, and social insurance standards will generate welfare migration and put pressure on social insurance institutions. So far there is little empirical evidence, though, on the way inter-European migrants assimilate in their host country. Moreover, in order to assess the long-term fiscal consequences of increased migration, it is necessary to acknowledge the considerable heterogeneity across immigrant groups. A lifecycle perspective is required, simply because labor migrant do not necessarily work permanently. Refugees and family immigrants typically start without a job and assimilate into the labor market over time.

In this paper, we draw on individual, longitudinal data and estimate lifecycle profiles of employment, earnings, and disability program participation for immigrant groups that are representative for the various immigration regimes to Norway over the past four decades. Such lifecycle assessments of labor market performance and social insurance outcomes form key inputs in the analysis of fiscal consequences of immigration, although we do not undertake a full accounting of fiscal implications. Our findings show that the impacts of labor immigration, in particular, depend crucially on the characteristics of the immigrants, and that the difference in living standards between the source country and the destination country is a particularly important predictor for their long-term labor market performance. Immigrants from countries with similar income levels as Norway tend to perform well in the Norwegian labor market, and on par with natives. A relatively low fraction of these immigrants settle permanently, however. Conversely, labor immigrants from low-income developing countries tend to stay over the long haul and have high risks of non-employment and social insurance dependency. 
Not surprisingly, we uncover very different economic performance profiles among immigrants admitted for reasons other than work. For refugees and family immigrants we find clear signs of assimilation during their first decade in Norway, with employment rates and earnings levels approaching - yet never fully catching up with - those of similar natives. Over the longer term, however, there is a tendency that immigrant-native performance differentials widen again. For all cohorts of immigrants from low-income countries that we can study for more than 10-15 years in the country, we find patterns of declining employment accompanied by rising participation in disability insurance. This "dissimilation" process is often triggered by a business cycle downturn with employment and earnings of immigrants much more sensitive to economic slumps than those of natives.

The pattern of declining long-term employment observed among immigrants from various lowincome source countries makes it natural to search for explanations in the structural characteristics of the destination country. The Norwegian labor market is characterized by a compressed wage structure with high effective minimum wages due to centralized bargaining and fairly strict employment regulations. This leads to a small service sector with relatively few low-skilled jobs. If the skill distribution of immigrants is more dispersed than that of natives, employment prospects of lowskilled immigrants may be hampered by the lack of jobs that match their skills (Bratsberg et al., 2013). Further, such labor market features go hand in hand with a relatively generous social insurance system that in turn may encourage some individuals who are (or could have been) capable of supporting themselves through employment to instead rely on social insurance. Immigrants often face high social insurance replacement ratios due to the progressive nature of benefit schedules and the additional allowances available to families with dependent children. For labor immigrants from low-income countries, the real value of social insurance benefits may also be significantly inflated by the possibility of exporting benefits to the country of origin where costs of living typically are much lower than in Norway. Even if the combination of a compressed wage structure and generous social insurance facilitates high overall employment and productivity, the same features may result in labor market barriers and weak work incentives for immigrants.

For the recent - and historically by far largest - immigrant wave from Eastern Europe, it is still too early to say whether the lifecycle patterns of declining employment and rising social insurance dependency will repeat themselves. Our study uncovers soaring unemployment rates - and much higher dependency on social insurance payments - during the financial crisis among recently arrived Eastern European workers than among similar native workers. However, we also see indications that employment levels bounced back relatively quickly once the labor market picked up again. After all, Eastern Europe is much closer to Norway, both economically, culturally, and geographically, than the developing countries from which earlier labor migrants to Norway originated. The sheer size of the migrant inflows may also imply that these migrants belong to large social and professional networks that make it easier to adapt to changed circumstances in the labor market, and also to move on or return to their source country during recessions in the host country.

In the longer run, the fiscal consequences of immigration also depend on the fertility, human capital investments and labor market performance of descendants. We have shown that the children of the 1970s non-European labor immigrant cohort obtained less education, and had lower employment and earnings, than natives of the same age. And again, we find a concerning tendency for high and growing disability program participation among second generation immigrants, possibly transmitted 
across generations. But even so, we uncover clear evidence of intergenerational assimilation and find that immigrant children born in Norway do better than those born abroad and much better than their parents. Exposure to the host country childhood environment in terms of subsidized child care, free health care, and high-expenditure public schooling seems to have favorable long-term effects on the economic status of children of immigrants from low-income source countries.

\section{References}

Åslund, O., and D.O. Rooth (2007), "Do When and Where Matter? Initial Labor Market Conditions and Immigrant Earnings," The Economic Journal, Vol. 117, Issue 518, 422-448.

Aizer, A., and J. Currie (2004), "Networks or Neighborhoods? Correlations in the Use of Publicallyfunded Maternity Care in California," Journal of Public Economics, Vol. 88, No. 12, 2573-2585.

Bauer, T.K., M. Lofstrom, and K.F. Zimmermann (2000), "Immigration Policy, Assimilation of Immigrants, and Natives' Sentiments towards Immigrants: Evidence from 12 OECD Countries," Swedish Economic Policy Review 7: 11-53.

Barth, E., B. Bratsberg, and O. Raaum (2004), "Identifying Earnings Assimilation of Immigrants under Changing Macroeconomic Conditions," Scandinavian Journal of Economics, Vol. 106, No. 1, 1-22.

Barth, E., B. Bratsberg, and O. Raaum (2012), "Immigrant Wage Profiles within and between Firms," Labour Economics, Vol. 19, No. 4, 541-556.

Bertrand, M., Luttmer, E. F. P., and Mullainathan, S. (2000) "Network Effects and Welfare Cultures," Quarterly Journal of Economics, Vol. 115, No. 3, 1019-1055.

Black, S.E., and P.J. Devereux, "Recent Developments in Intergenerational Mobility." In O. Ashenfelter and D. Card (eds), Handbook of Labor Economics, Elsevier, 1487-1541.

Blau, F.D., L.M. Kahn, and K.L. Papps (2011), "Gender, Source Country Characteristics and Labor Market Assimilation among Immigrants, 1980-2000," Review of Economics and Statistics 93(1): 43-58.

Boeri, T. (2010), "Immigration to the Land of Redistribution," Economica, Vol. 77, No. 308, 651-687.

Böhlmark, A. (2008), "Age at immigration and school performance: A siblings analysis using Swedish register data," Labour Economics, Vol. 15, No. 6, 1366-1387.

Böhlmark, A. (2009), "Integration of Childhood Immigrants in the Short and Long Run - Swedish Evidence," International Migration Review, Vol. 43, No. 2, 387-409.

Borjas, G.J., and B. Bratsberg (1996), "Who Leaves? The Outmigration of the Foreign Born," The Review of Economics and Statistics, Vol. 78, No. 1, 165-176.

Borjas, G.J., and S. Trejo (1993), "National Origin and Immigrant Welfare Recipiency," Journal of Public Economics, Vol. 50, No. 3, 325-344.

Bratsberg, B., E. Barth, and O. Raaum (2006), "Local Unemployment and the Relative Wages of Immigrants: Evidence from the Current Population Surveys," The Review of Economics and Statistics, Vol. 88, No. 2, 243-263.

Bratsberg, B., E. Fevang, and K. Røed (2013), "Job Loss and Disability Insurance," Labour Economics, Vol. 24, October, 137-150.

Bratsberg, B.,T. Hægeland, and O. Raaum (2013), "Immigrant Skills and Employment: Cross-country Evidence from the Adult Literacy and Life Skills Survey," Statistics Norway Discussion Paper No. 730. 
Bratsberg, B., O. Raaum, and K. Røed (2010), "When Minority Labor Migrants Meet the Welfare State," Journal of Labor Economics, Vol. 28, No. 3, 633-676.

Bratsberg, B., O. Raaum, and K. Røed (2012), "Educating Children of Immigrants: Closing the Gap in Norwegian Schools," Nordic Economic Policy Review 1/2012, 211-253.

Bratsberg, B., O. Raaum, and K. Røed (2014), "Labour Migrant Adjustments in the Aftermath of the Financial Crisis," Discussion paper 19/14, Centre for Research and Analysis of Migration, University College London.

Brinch, C., B. Bratsberg, and O. Raaum (2012), "The Effects of an Upper Secondary Education Reform on the Attainment of Immigrant Youth," Education Economics, Vol. 20, No. 5, 447-473.

Brochmann, G., and K. Kjeldstadli (2008). A history of immigration: The case of Norway 900-2000. Oslo: Universitetsforlaget.

Casey, T., and C. Dustmann (2008), "Intergenerational Transmission of Language Capital and Economic Outcomes," Journal of Human Resources, Vol. 43, No. 3, 660-687.

Dahl, G., A. Kostøl, and M. Mogstad (2013), "Family Welfare Cultures," NBER Working Paper No. 19237.

Dustmann, C., A. Glitz, and T. Vogel (2010), "Employment, Wages, and the Economic Cycle: Differences between Immigrants and Natives," European Economic Review, Vol. 54, No. 1, 1-17.

Dustmann, C., and T. Frattini (2013), "The Fiscal Effects of Immigration to the UK," CReAM Discussion Paper No. 22/13, University College, London.

Economist (2012), "Liberalising migration could deliver a huge boost to global output," Nov $17^{\text {th }}$ 2012, p. 72.

Kennan, J. (2012), “Open Borders," Review of Economic Dynamics, Vol. 16, No. 2, L1-L13.

Markussen, S., and K. Røed (2014), "Social Insurance Networks," Journal of Human Resources, forthcoming.

Nannestad, P. (2004), "Immigration as a Challenge to the Danish Welfare State?" European Journal of Political Economy, Vol. 20, No. 3, 755-767.

Preston, I. (2013), "The Effect of Immigration on Public Finances," CReAM Discussion Paper No. 23/13, University College, London.

Rege, M., K. Telle, and M. Votruba (2009), "The Effect of Plant Downsizing on Disability Pension Utilization," Journal of the European Economic Association, Vol. 7, No. 5, 754-785.

Sarvimäki, M. (2011), "Assimilation to a Welfare State: Labor Market Performance and Use of Social Benefits by Immigrants to Finland," Scandinavian Journal of Economics, Vol. 113, No. 3, 665-688.

Statistics Norway (2014), "Immigrants and Norwegian-born to immigrant parents," http://www.ssb.no/en/befolkning/statistikker/innvbef/aar (accessed May 8, 2014).

Storesletten, K. (2003), "Fiscal implication of immigration - a net present value calculation," Scandinavian Journal of Economics, Vol. 105, No. 3, 487-506.

Tunali, I. (1986), "A General Structure for Models of Double Selection and an Application to a Joint Migration/Earnings Process with Remigration," Research in Labor Economics, Vol. 8, 235-282. 
Appendix Table A-1: Employment and log earnings of outmigrants and stayers

\begin{tabular}{|c|c|c|c|c|c|c|c|}
\hline \multirow[b]{3}{*}{ Immigrant cohort } & I & II & III & IV & V & & VII \\
\hline & \multicolumn{3}{|c|}{$\underline{\text { Percent outmigrated within }}$} & \multicolumn{2}{|c|}{ Employment rate } & \multicolumn{2}{|c|}{$\begin{array}{l}\text { Log earnings if } \\
\text { employed }\end{array}$} \\
\hline & 5 yrs & 10 yrs & 15 yrs & $\begin{array}{l}\text { Outmig } \\
@ 5 \text { yrs }\end{array}$ & Stayers & $\begin{array}{l}\text { Outmig } \\
@ 5 \text { yrs }\end{array}$ & Stayers \\
\hline \multicolumn{8}{|l|}{ A. Men } \\
\hline Western Europe 1971-75 & 58.7 & 64.4 & 67.9 & 0.896 & $0.858 * * *$ & 12.518 & $12.410 * * *$ \\
\hline Pakistan/Turkey 1971-75 & 9.8 & 12.2 & 14.4 & 0.981 & 0.974 & 12.201 & $12.263 * *$ \\
\hline Pakistan/Turkey 1986-90 & 19.9 & 32.7 & 35.9 & 0.157 & $0.538 * * *$ & 11.764 & $11.997 * *$ \\
\hline Refugees 1986-90 & 8.1 & 16.8 & 21.0 & 0.239 & $0.388 * * *$ & 11.888 & 11.905 \\
\hline Balkans 1991-95 & 22.2 & 25.4 & 26.6 & 0.089 & $0.255^{* * *}$ & 11.769 & 11.857 \\
\hline Refugees 1996-2000 & 14.1 & 19.6 & 23.1 & 0.559 & $0.509 * * *$ & 12.121 & 12.104 \\
\hline New EU 2004-07 & 22.5 & $\mathrm{~N} / \mathrm{A}$ & N/A & 0.637 & $0.910 * * *$ & 12.341 & $12.614^{* * *}$ \\
\hline \multicolumn{8}{|l|}{ B. Women } \\
\hline Western Europe 1971-75 & 63.0 & 69.6 & 71.7 & 0.762 & $0.583^{* * *}$ & 12.146 & 12.133 \\
\hline Pakistan/Turkey 1971-75 & 8.4 & 10.1 & 11.7 & 0.750 & $0.216^{* * *}$ & 11.425 & $11.863^{*}$ \\
\hline Pakistan/Turkey 1986-90 & 5.0 & 10.6 & 13.1 & 0.071 & 0.111 & 11.614 & 11.793 \\
\hline Refugees 1986-90 & 8.0 & 16.5 & 20.6 & 0.160 & $0.210 * *$ & 11.725 & 11.743 \\
\hline Balkans 1991-95 & 17.7 & 20.1 & 20.8 & 0.092 & $0.147^{*}$ & 11.637 & 11.782 \\
\hline Refugees 1996-2000 & 7.6 & 12.4 & 18.1 & 0.095 & 0.124 & 12.896 & 12.803 \\
\hline New EU 2004-07 & 14.3 & N/A & N/A & 0.408 & $0.679 * * *$ & 12.140 & $12.321 * * *$ \\
\hline
\end{tabular}

$* / * * / * * *$ Significantly different from mean for outmigrants at 10/5/1 percent level.

Note: Mean outcomes in cols IV and VI are for the subsample that outmigrated 3 or 4 years after arrival and in cols $V$ and VIII for those who stayed at least 5 years. 
Appendix Table A-2: Predicted relative change in employment and log earnings between 5 and 15 years since arrival, full sample vs panel

\begin{tabular}{|c|c|c|c|c|}
\hline \multirow[b]{3}{*}{ Immigrant cohort } & 1 & II & III & IV \\
\hline & \multicolumn{2}{|c|}{ Employment } & \multicolumn{2}{|c|}{$\underline{\text { Log earnings }}$} \\
\hline & $\begin{array}{c}\text { Full sample } \\
\text { (see section 3) }\end{array}$ & $\begin{array}{c}\text { Panel } \\
\text { (in Norway } 5 \text { and } \\
15 \text { yrs after arr) }\end{array}$ & $\begin{array}{c}\text { Full sample } \\
\text { (see section 3) }\end{array}$ & $\begin{array}{c}\text { Panel } \\
\text { (employed } 5 \text { and } \\
15 \text { yrs after arr) }\end{array}$ \\
\hline \multicolumn{5}{|l|}{ A. Men } \\
\hline \multirow[t]{2}{*}{ Western Europe 1971-75 } & 0.007 & 0.021 & 0.021 & 0.049 \\
\hline & $(0.006)$ & $(0.006)$ & (0.011) & $(0.012)$ \\
\hline \multirow[t]{2}{*}{ Pakistan/Turkey 1971-75 } & -0.144 & -0.150 & -0.099 & -0.097 \\
\hline & $(0.007)$ & $(0.007)$ & $(0.010)$ & $(0.012)$ \\
\hline \multirow[t]{2}{*}{ Pakistan/Turkey 1986-90 } & 0.076 & 0.046 & 0.128 & 0.136 \\
\hline & $(0.012)$ & $(0.013)$ & $(0.011)$ & $(0.022)$ \\
\hline \multirow[t]{2}{*}{ Refugees 1986-90 } & 0.177 & 0.164 & 0.180 & 0.161 \\
\hline & $(0.006)$ & $(0.013)$ & $(0.008)$ & $(0.011)$ \\
\hline \multirow[t]{2}{*}{ Balkans 1991-95 } & 0.061 & 0.048 & 0.114 & 0.104 \\
\hline & $(0.011)$ & $(0.011)$ & $(0.013)$ & $(0.014)$ \\
\hline \multirow[t]{2}{*}{ Refugees 1996-2000 } & -0.079 & -0.091 & -0.060 & -0.052 \\
\hline & $(0.011)$ & $(0.012)$ & $(0.015)$ & (0.019) \\
\hline \multicolumn{5}{|l|}{ B. Women } \\
\hline \multirow[t]{2}{*}{ Western Europe 1971-75 } & 0.024 & 0.052 & 0.004 & 0.065 \\
\hline & $(0.008)$ & $(0.008)$ & $(0.011)$ & $(0.014)$ \\
\hline \multirow[t]{2}{*}{ Pakistan/Turkey 1971-75 } & -0.116 & -0.122 & -0.149 & -0.023 \\
\hline & $(0.013)$ & $(0.014)$ & $(0.030)$ & $(0.056)$ \\
\hline \multirow[t]{2}{*}{ Pakistan/Turkey 1986-90 } & 0.137 & 0.136 & 0.065 & 0.060 \\
\hline & $(0.014)$ & $(0.015)$ & $(0.030)$ & $(0.067)$ \\
\hline \multirow[t]{2}{*}{ Refugees 1986-90 } & 0.248 & 0.244 & 0.228 & 0.193 \\
\hline & (0.009) & $(0.010)$ & $(0.012)$ & (0.019) \\
\hline \multirow[t]{2}{*}{ Balkans 1991-95 } & 0.169 & 0.165 & 0.171 & 0.173 \\
\hline & $(0.013)$ & $(0.013)$ & (0.014) & (0.017) \\
\hline \multirow[t]{2}{*}{ Refugees 1996-2000 } & 0.120 & 0.123 & -0.009 & 0.082 \\
\hline & $(0.015)$ & $(0.015)$ & $(0.029)$ & $(0.092)$ \\
\hline
\end{tabular}

Note: Table entry is the predicted change in the immigrant-native difference between 5 and 15 years after arrival. 